\title{
REVISED COMPUTER PROGRAMS FOR ORDERING, LISTING, AND CIRCULATING LIBRARY BOOKS
}

\author{
MYRA S. FELDMAN \\ H. FRANCES WREN \\ NORMA A. BUHL
}

IS FILE

RECORD COPY

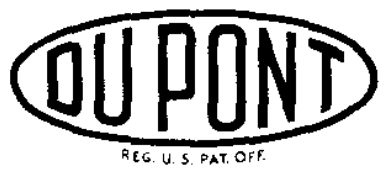

E. I. du Pont de Nemours \& Co.

Savannah River Laboratory

Aiken, S. C. 29801 


\section{NOTICE}

This report was prepared as an account of work sponsored by the United States Government. Neither the United States nor the United States Energy Fesearch and Development Administration, nor any of their contractors, subcontractors, or theif employees, makes any warranty. express or implied, or assumes any legal liability or responsibility for the accuracy, complateness or usefulness of any information, apparatus, product or process disclosed, or represents that its use would not infringe privately owned rights.

Printed in the United States of America Available from

National Technical Information Service

U. S. Department of Commerce

5285 Port Royal Road

Springfield, Virginia 22161

Price: Printed Copy \$5.45; Microfiche \$2.25 


\title{
REVISED COMPUTER PROGRAMS FOR ORDERING, LISTING, AND CIRCULATING LIBRARY BOOKS
}

\author{
by \\ Myra S. Feldman \\ H. Frances Wren \\ and \\ Norma A. Buh? \\ Approved by \\ J. R. Hilley, Research Manager \\ Computer Applications Division \\ and \\ S. W. O'Rear, Supervisor \\ Technical Information Service \\ Publication Date: August 1975
}

\section{E. I. du Pont de Nemours \& Co. Savannah River Laboratory Aiken, S. C. 29801}




\begin{abstract}
The Technical Library of the Savannah River Laboratory uses COBOL programs to assist in purchasing and circulating books and to provide book lists and printed catalogs. The programs are written for the IBM System/360-195 with $2 \mathrm{kk}$ byte storage capacity and may be used by a library of any size. "Bibliographic and cataloging data for the library holdings are stored on magnetic tape from which data can be recalled in twenty-nine printout options to retrieve information concerning borrowers, authors, subject matter, inventory, etc. Book ordering is simplified, requixing only key-punched data cards as input and obtaining multiple purchase order forms as printout.

The programs are improved over those reported earlier as follows: The data are more compact. Subject, series, and crossreference files are maintained in the computer memory bank. Manual handling and sorting operations have been eliminated; thus keypunching of data input cards is the only manual operation remaining.
\end{abstract}




\section{CONTENTS}

Page

Introduction . . . . . . . . . . . . . . 7

General Description of Programs . . . . . . . . . 9

Book Order Program . . . . . . . . . . . . . 11

Book Control Program . . . . . . . . . . . 13

Appendix A. Data Input for Book Order Program . . . . . 19

Appendix B. Master File for Book Control Program . . . 23

Subject Data Input ............. . 23

Series Data Input . . . . . . . . . . . . 24

Subject Cross-Reference Data Input . . . . . . 25

Book Information Data Input... . . . . . . 26

Changing Book Data .. . . . . . . . . . . 33

Deleting Book Data ............. . . 34

Deleting Part of Book Data . . . . . . . . 35

Report Request Card . . . . . . . . . . 36

Appendix $C$. Functional Operation of the Book

Control Program . . . . . . . . . . 41

Initial Scrub (Step 1) ............. . . 41

Card Image Sort Program (Step 2) . . . . . . . . 42

Update and Report Program (Step 3) . . . . . . . 42

Update Functions . . . . . . . . . . . 42

Report Functions . . . . . . . . . . . . 44

Report Sort Program (Step 4) .......... . 45

Printout Program (Step 5) ........... . 46

Appendix D. Input and Error List for Update Program . . . 53 


\section{LIST OF FIGURES AND TABLES}

Figure

Page

1. Library Procedure Flowchart .......... . 10

2. Book Order Flowchart. ............. 11

3. Book Order Printout . . . . . . . . . . . 12

4. Book Control Program. . . . . . . . . . . 13

5. Summary of Report Sort Fields . . . . . . . . 14

6. Book Card T. . . . . . . . . . . . . 19

7. Book Card 2............... . . 20

8. Book Card 3................ . . 21

9. Subject Input Card . . . . . . . . . . 23

10. Series Input Card . . . . . . . . . . 24

11. Subject Cross-Reference Card . . . . . . . 25

12. Book Card 4 (Primary Information) . . . . . . 26

13. Book Card 5 (Numeric Codes for Subject Headings). . 28

14. Book Card 6 (Secondary Authors and Titles). . . . 29

15. Book Card 7 (Extended Title) ......... 30

16. Book Card 8 (Additional Series) . . . . . . . 31

17. Book Card 9 (Charge-out) . . . . . . . . 32

18. Change Card Format (Update or Correction) . . . 33

19. Book Deletion Format ........... . . 34

20. Card Image Deletion Format . . . . . . . . 35

21. Report Request Card . . . . . . . . . . 36

22. Request Card for Report Code 24 (Al1 Books Charged to an Individual) .......... . . 37 
23. Loan Card Submitted for Report Code 25

(Recall Notices)............. 38

24. Request Card for Report Code 27 (A11 Books

Cataloged under a Single Subject) . . . . . 39

25. Report Request Deck . . . . . . . . . . 4 ?

26. Flowchart for Initial Scrub Program ....... 41

27. Flowchart for Card Image Sort Program . . . . . 42

28. Report Flow Chart ............. 45

29. Flowchart for Report Sort Program . . . . . . 46

30. Flowchart for Print Program. . . . . . . . 46

31. A11 Books by Author, Title, and Accession Number (Report Codes 1 and 2) .......... 47

32. All Books with Call Number by Author and Title (Report Codes 3 and 4) . . . . . . . . . 47

33. Ali Books with Call Number by Call Number

(Report Codes 5 and 6) ........... . 47

34. A11 Books by Departmental Cost Code and Date Received (Report Code 7) . . . . . . . . 48

35. A11 Books by Accession Number (Report Codes 8 and 9) . . . . . . . . . 48

36. Al1 Books with Series by Series (Report Codes 10 and 11) .......... 48

37. Al1 Books with Call Number and Series by Series (Report Codes 12 and 13) .......... 48

38. Al1 Books with Call Number by Subject and Author (Report Codes 14 and 15) .......... 49

39. A11 Books by Title and Author (Report Codes 16 and 17) .......... 49

40. A17 Books on Loan by Author and Title (Report Code 18) ............. 
41. All Books on Loan by Borrower, Author, and Title (Report Code 19) .............

42. All Books with Call Number by Title and Author (Report Codes 20 and 21) ......... 50

43. A11 Books without Call Number by Requester, Author, and Title (Report Codes 22 and 23) . . . 50

44. A7l Books Loaned to a Borrower by either Requester or Borrower (Report Code 24) . . . . 50

45. All Books with Call Number Loaned to a Borrower by Borrower, Author, and Title (Report Code 25). . 51

46. A11 Books without Cal1 Number by Requester, Author, and Accession Number (Report Code 26) . . . . . 51

47. All Books Cataloged under a Particular Subject (Report Code 27) . . . . . . . . 51

48. A11 Series and Subject Codes with their Corresponding Alphabetic Headings (Report Code 28). . . 51

49. A11 Subject Cross-References (Report Code 29) . . . 52

Table

I Request Options and Applications . ...... . 15 


\section{REVISED COMPUTER PROGRAMS FOR ORDERING, LISTING, AND CIRCULATING LIBRARY BOOKS}

\section{INTRODUCTION}

The Technical Library of the Savannah River Laboratory uses an IBM System/360-195 with $2 \mathrm{kk}$ storage to process book orders and to control the circulation of over 22,000 books and monographs. Many time-consuming and repetitive library operations have been automated to provide better and additional service to library users.

The library serves the Savannah River Laboratory (SRL), the Savannah River Plant (SRP), and the Savannah River Operations office (SR). The facilities for these organizations are located near Aiken, South Carolina. E. I. du Pont de Nemours and Company operates the laboratory and the plant for the U. S. Energy Research and Development Administration (ERDA). The library, staffed with three librarians and four assistants, is concerned primarily with atomic energy and its related science disciplines.

Two COBOL programs have been developed: the Book Order Program and the Book Control Program. The Book Order Program prepares purchase orders for books. The Book Control Program stores bibliographic and cataloging data on a master tape that is updated periodically. Twenty-nine different options can be used to recall the data. These options provide catalog 1 istings of all books in the library as well as lists of books on loan and those charged permanently to individuals and departments. There is no limit to the number of books that can be processed by these programs.

The present programs are a revision of earlier COBOL programs.* The programs were changed to compact the data, thus reducing the number of input cards and the amount of computer storage required. Card formats were altered to facilitate processing and handling of cards and to control tape assignments. Subject, series, and crossreference files are maintained by the computer rather than manually maintained by library personne1. Error messages were expanded and revised.

ॠN. A. Buh1 and M. S. Feldman. Computer Programs for Ordering, Listing, and Circulating Library Books. USAEC Report DP-1113, E. I. du Pont de Nemours \& Co., Savannah River Laboratory, Aiken, S. C. (1967). 
$-8-$ 


\section{GENERAL DESCRIPTION OF PROGRAMS}

The library procedures for ordering, processing, circulating, recalling, and listing books are shown in Figure 1.

As each book is ordered, a unique accession number is assigned to it. This accession number is added to each of the punched cards necessary for a "book record." The order clerk keypunches three book cards when ordering a book. The Book Order Program prints purchase orders from these cards. Before the use of computer programs, the order clerk typed multiple (6) copies of book orders on 3-in. x 5-in. preprinted purchase order forms. Three of these slips were filed, one was sent to the book vendor and the remaining two were used for the Library of Congress card order. Only four computer-printed slips are needed and are distributed as shown on Figure 1. Three separate files (requestor, author, and item number) maintained by the order clerk are replaced by printouts from the Book Control Program.

When a book is received, the book and the three cards punched by the order clerk are given to the technical processing personnel. The book is cataloged, and additional cards are keypunched. The additional data include all bibliographic and cataloging information. As few as four or as many as thirteen punched cards may be needed. The Book Control Program stores the bibliographic and cataloging data on a master tape. The master tape is updated as new books are received or as the status of a book changes. Partial or complete printouts may be obtained on demand. These printouts replace eight manual files previously maintained by library personnel. Printouts from the Book Control Program provide:

- She1f lists

- Author, title, series, and subject catalogs

- Subject bibliographies

- Purchase and accounting records

- Inventory contro1

- Accurate control over desk or departmental materials, surplus books, and lost books

- Circulation records

- Recall notices

At the circulation desk, only one charge-out card file of punched cards is kept; before the computerized system, two chargeout card files were necessary. The Book Control Program produces two printouts of all books on loan: one alphabetically by authors and the other alphabetically by borrowers. Recall notices are also obtained as computer printouts, eliminating handwritten preprinted forms. 


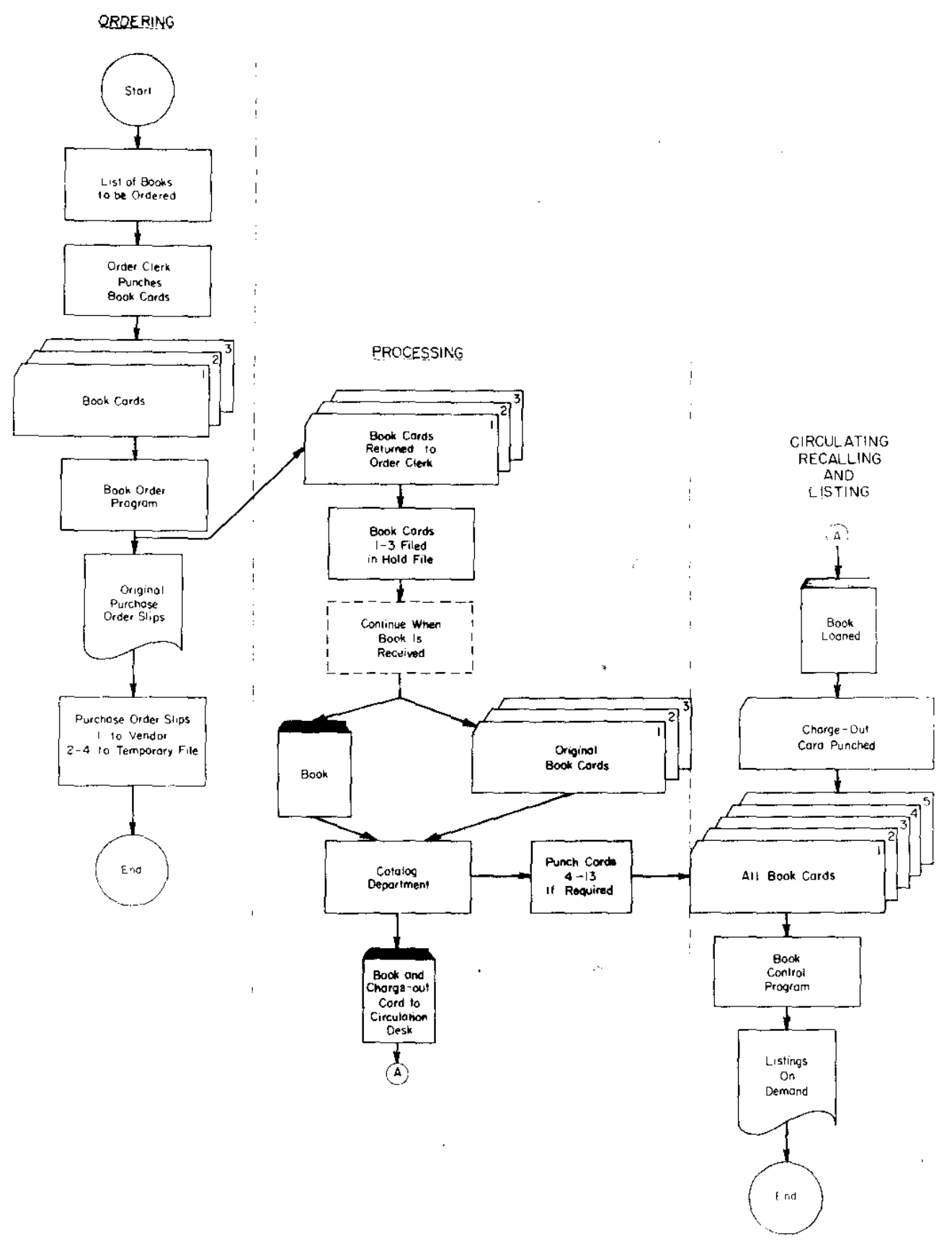

FIG. 1 LIBRARY PROCEDURE FLOWCHART 


\section{BOOK ORDER PROGRAM}

The flowchart for ordering books is shown schematically in Figure 2. To initiate a book order, the library order clerk keypunches three data cards per book from original order requests (see Appendix A). These data cards are combined with a small COBOL source deck for each computer run. There is no upper limit on the number of books ordered at any one time.

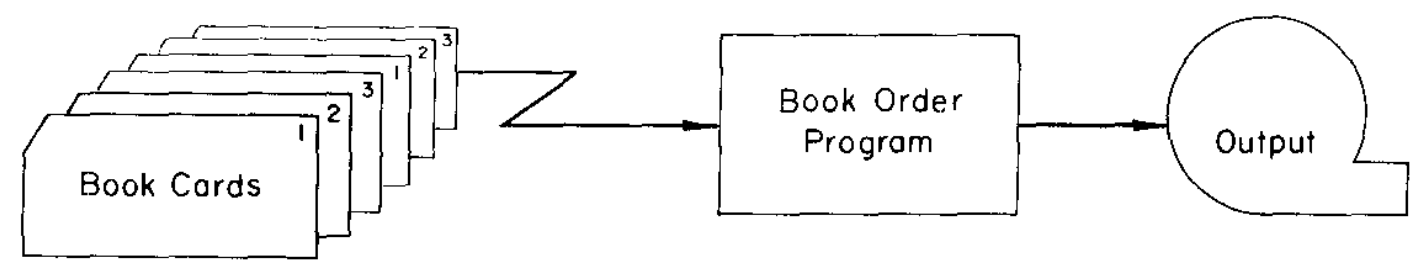

FIG. 2 BOOK ORDER FLOWCHART

Output from the Book Order Program is written on magnetic tape. The information on this tape is then printed, eight lines per inch, on un 1 ined 10 in. $x 14$ in. paper. Four original purchase order forms are printed for each book (Figure 3). The printout sheets are cut to provide standard 3 in. $x 5$ in. order forms. Since headings are underlined, preprinted forms are not necessary.

The four copies of the order form are distributed as follows: 1) vendor, 2) on-order file, 3) claim file, and 4) accession number file. 


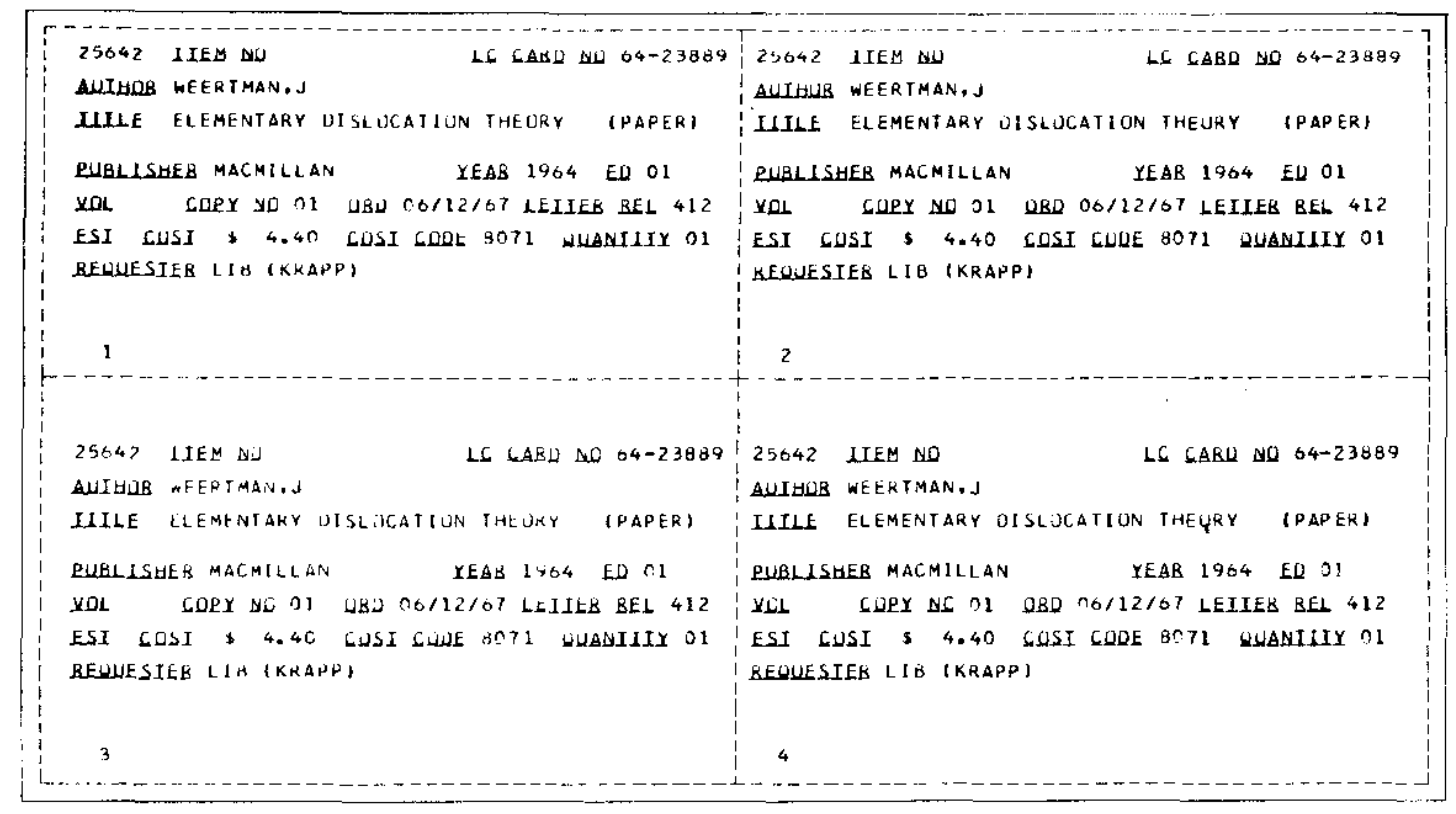

FIG. 3 BOOK ORDER PRINTOUT 


\section{BOOK CONTROL PROGRAM}

The Book Contro1 Program consists of five program steps (Figure 4 and Appendices $B$ and $C$ ). Each program step, however, may be executed as a separate program. All update data for the Master File are submitted in a single card deck to the Initial Scrub Progrom. The work file produced by this program is used as input to the Card Image Sort Program. The sorted work file, the old Master File, and a Report Request File are input to the Update and Report Progrom, which produces a new Master File and also a Report Work File containing information pertinent to the reports requested. The old Master File is retained as a backup file. After the Report Work File is sorted by the Report Sort Program, the Printout Program uses the sorted work file to generate the report listings that have been requested.

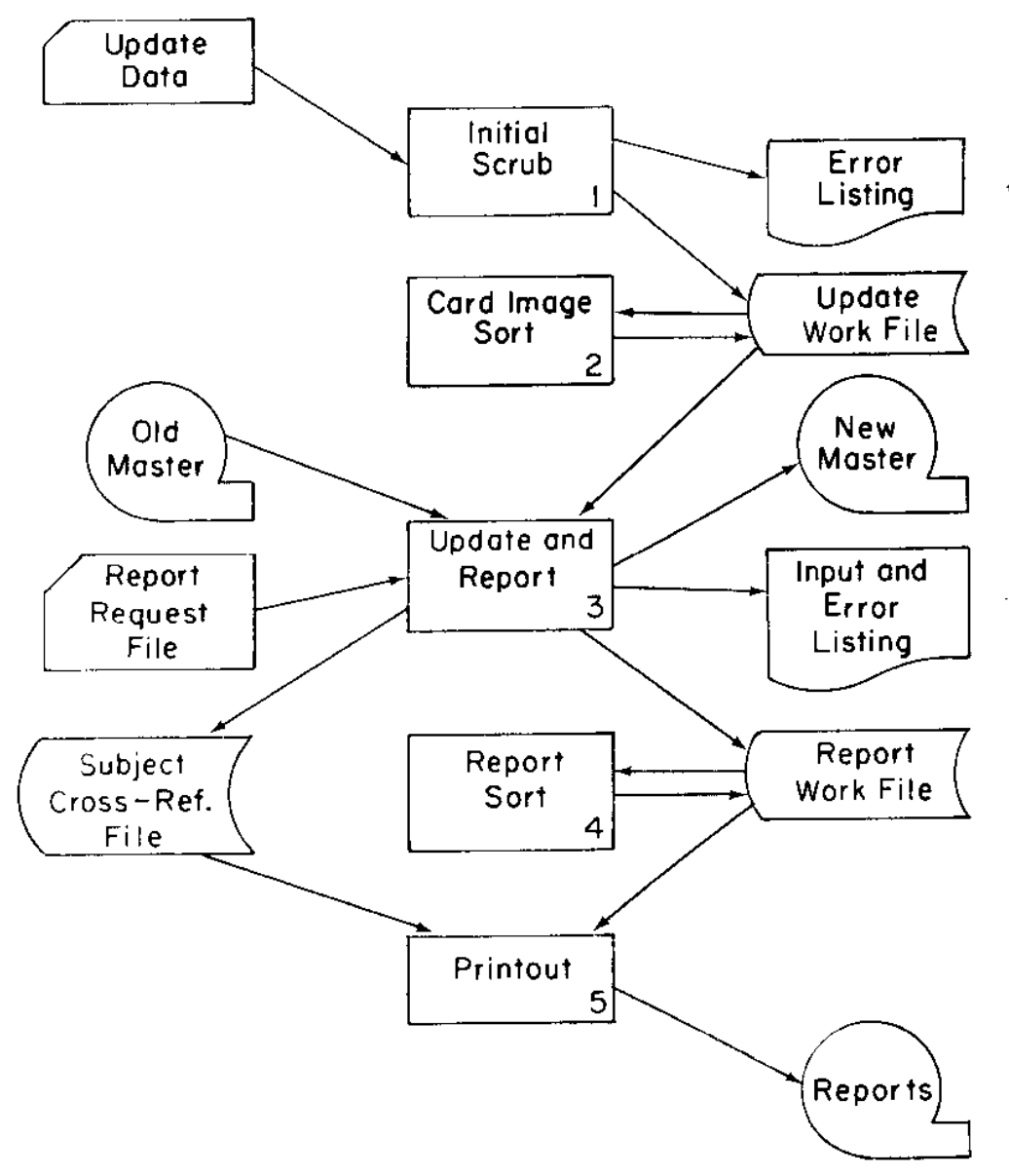

FIG. 4 BOOK CONTROL PROGRAM 
Twenty-nine different request options can be reported. These output reports are parallel to and replace all cataloged, bibliographic, and accounting files that must be maintained by library personne1. Table $I$ and Figure 5 list the report codes and report listings available. The master item is a major sort, and the cumulative item is a secondary sort.
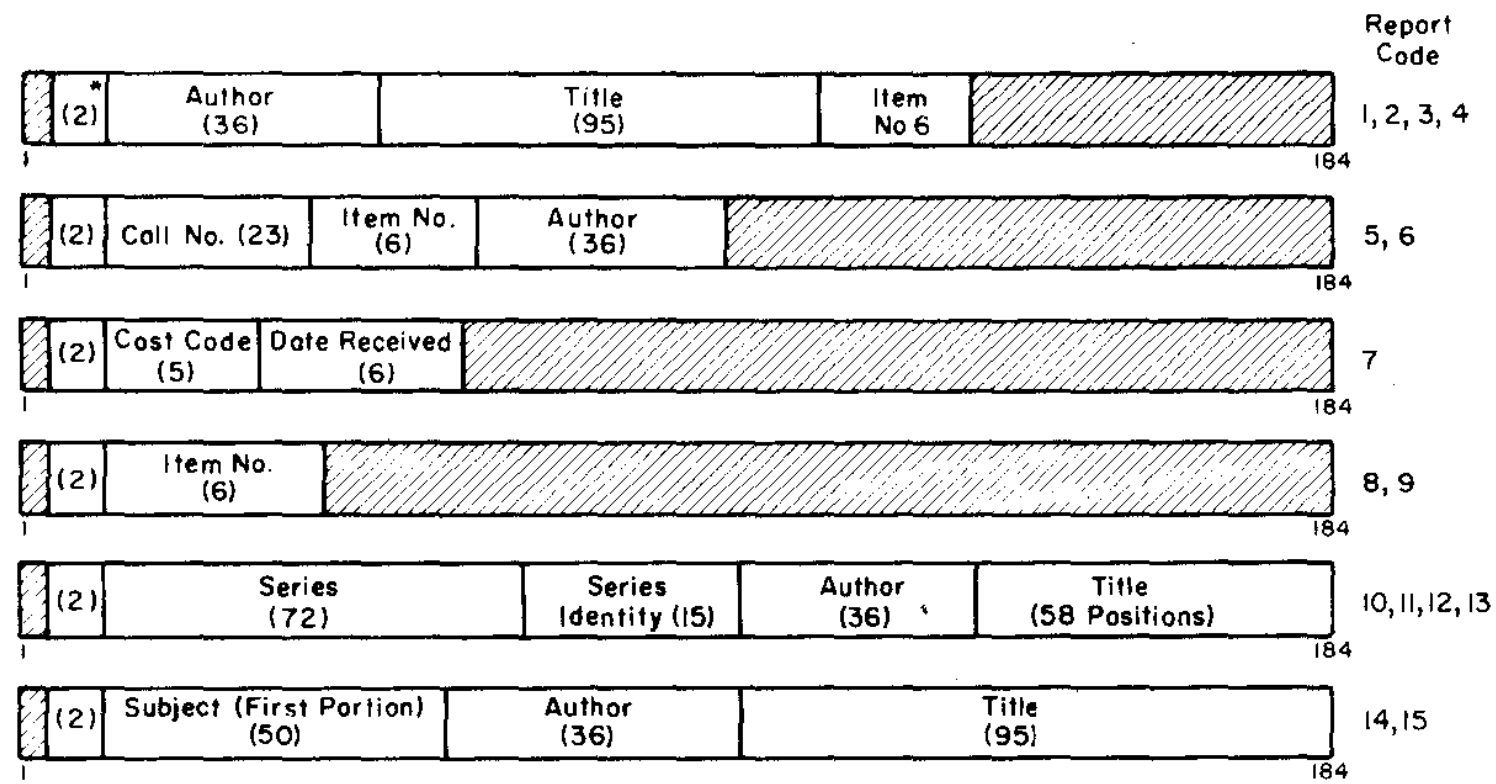

\begin{tabular}{|c|c|c|c|c|}
\hline (2) & $\begin{array}{l}\text { Tifle } \\
(95)\end{array}$ & $\begin{array}{l}\text { Author } \\
\text { (36) }\end{array}$ & $\begin{array}{c}\text { Call No } \\
\text { (23) }\end{array}$ & $16,17,20,21$ \\
\hline
\end{tabular}
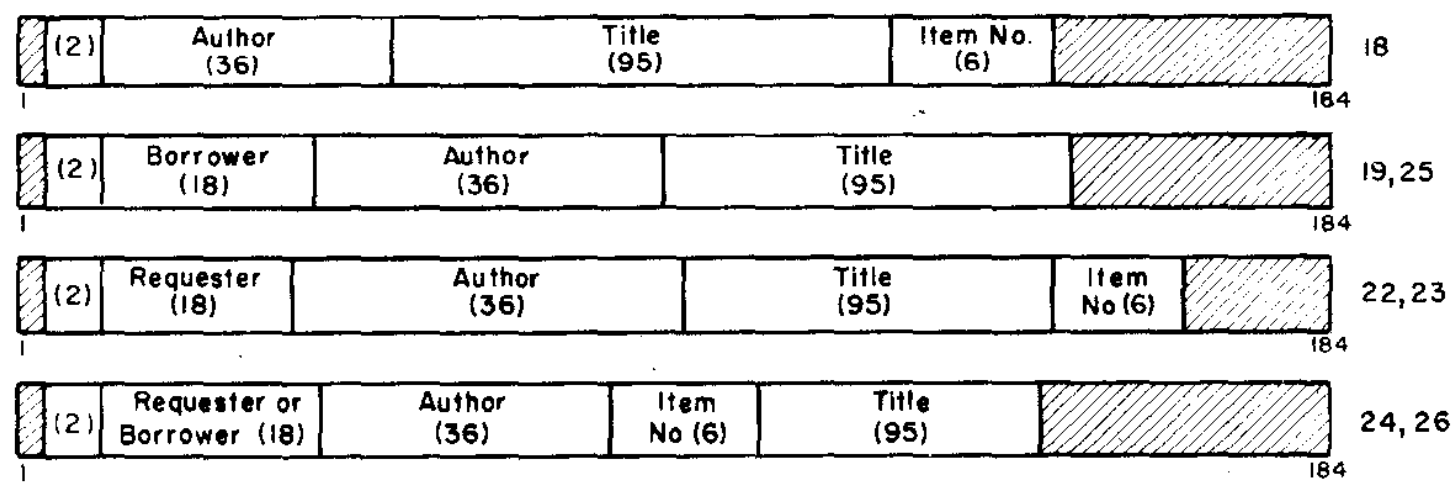

\begin{tabular}{|c|c|c|c|c|c|}
\hline$(2)$ & $\begin{array}{l}\text { Cross-Ref. } \\
\text { Code (6) }\end{array}$ & $\begin{array}{c}\text { Subject, Series, or } \\
\text { Subject Cross-Reference Heoding (72) }\end{array}$ & $\begin{array}{l}\text { Subj. or } \\
\text { Ser. No. (6) }\end{array}$ & 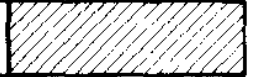 & 28,29 \\
\hline
\end{tabular}

* Report Code identification Number

(Not To Scale)

FIG. 5 SUMMARY OF REPORT SORT FIELDS 
TABLE I

Request Options and Applications

Report

Code

Request Option

01 (master) All books by author, title, and accession number.

02 (cumulative) Books added since last master printout by author, title, and accession number.

Report codes 01 and 02 give complete listings of all books (1ibrary, departmental, surplus, lost) to replace master author file.

03 (master) All books with call number by author and then title.

04 (cumulative) Books added since last master printout with call number by author and then titile.

Report codes 03 and 04 give complete listings of all cataloged library material. Copies of this printout replace the author file in reading room and are sent to plant areas remote from the library.

05 (master) All books with call number by call number.

06 (cumulative) Books with call number added since last master printout by call number.

Report codes 05 and 06 give complete listings of cataloged library material to replace shelf-list file, to provide subject bibliographies according to Library of Congress classification, and to facilitate shelf inventory.

07

(master)

Al1 books by departmental cost code and date received.

Report code 07 gives a complete listing of all books purchased by individual departments but not kept on Library shelves (desk copies).

08

(master) All books by accession number. 

accession number.

Report codes 08 and 09 give complete listings of all books to replace master accession number file and to provide accurate accounting for all library items.

11 (cumulative) Books with series added since last master printout by series.

Report codes 10 and 1 I give complete listings of all hooks to provide a master series listing.

Al1 books with call number and series by series.

13 (cumulative) Books with call number and series added since last master printout.

Report codes 12 and 13 give complete listings of all cataloged material to replace this portion of the card catalog. then author.

(cumulative) Books with call number added since last master printout by subject and then author.

Report codes 14 and 15 give complete listings of a1l
cataloged material to replace this portion of the card
catalog. A book may be listed under as many as 11
different subjects.

(master) All books by title and then author.

17 (cumulative) Books added since last master printout by title and then author.

Report codes 16 and 17 give complete listings of all books and their present status, whethex library or desk copies, surplus, or lost books. 
19 (master)

A11 books on 1 oan by borrower, then author and title.

Report codes 18 and 19 give two printouts to control the circulation of library material.

(master)

All books with call number by title and then author.

21 (cumulative) Books with call number added since last master printout by title and then author.

Report codes 20 and 21 give complete listings of all cataloged material to replace this portion of the card catalog and to provide listing of new acquisitions. Several of the above listings could also be used for new acquisition lists for current awareness programs depending upon styles desired.

A11 books without call number by requester, then author and title.

(cumulative) Books without call number added since last master printout by requester, author, and title.

Report codes 22 and 23 give complete listings of all departmental and desk copies, surplus, and lost books to eliminate a departmental book file.

Report code 24 is used for accounting purposes for an individual being transferred or terminated; also eliminates typing a list of an individual's books and gives in one print format the library copies and desk copies charged to that individual. (Upper limit of 200 requests per run.)

25 (master)

All books with call number loaned to a particular individual. Printout lists borrower, author, and title.

Report code 25 is used for recall notices only. (Upper limit of 200 recall requests per run).

20 (master) Al1 books without call number. Printout lists the author and the accession number.

Report code 26 is used for inventory of departmental or desk copies. 
Report code 27 is used for subject bibliographies. (Upper limit of 200 requests per run.)

A11 series and subject codes with their corresponding alphabetic headings. (Used by Library personnel in assigning codes).

29 (master) All subject cross-references. (Used by Library personnel in assigning codes.) 

and title.

Report codes 18 and 19 give two printouts to control the circulation of library material.

(master)

All books with call number by title and then author.

(cumulative) Books with call number added since last master printout by title and then author.

Report codes 20 and 21 give complete listings of all cataloged material to replace this portion of the card catalog and to provide listing of new acquisitions. Several of the above listings could also be used for new acquisition lists for current awareness programs depending upon styles desired.

A11 books without cal1 number by requester, then author and tit1e.

23 (cumulative) Books without call number added since last master printout by requester, author, and title.

Report codes 22 and 23 give complete listings of all departmental and desk copies, surplus, and lost books to eliminate a departmental book file.

24 (master) All books loaned to a particular individual.

Report code 24 is used for accounting purposes for an individual being transferred or terminated; also eliminates typing a list of an individual's books and gives in one print format the library copies and desk copies charged to that individual. (Upper limit of 200 requests per run.)

25 (master) All books with call number loaned to a particular individual. Printout lists borrower, author, and title.

Report code 25 is used for recal1 notices only. (Upper limit of 200 recall requests per run).

26 (master) Al1 books without call number. Printout lists the author and the accession number.

Report code 26 is used for inventory of departmental or desk copies. 


\section{APPENDIX A Data Input for Book Order Program}

Three data cards (Figures 6 through 8) constitute the input to the Book Order Program. Data in all fields are left-justified unless otherwise noted. Periods are not used after initials or abbreviations.

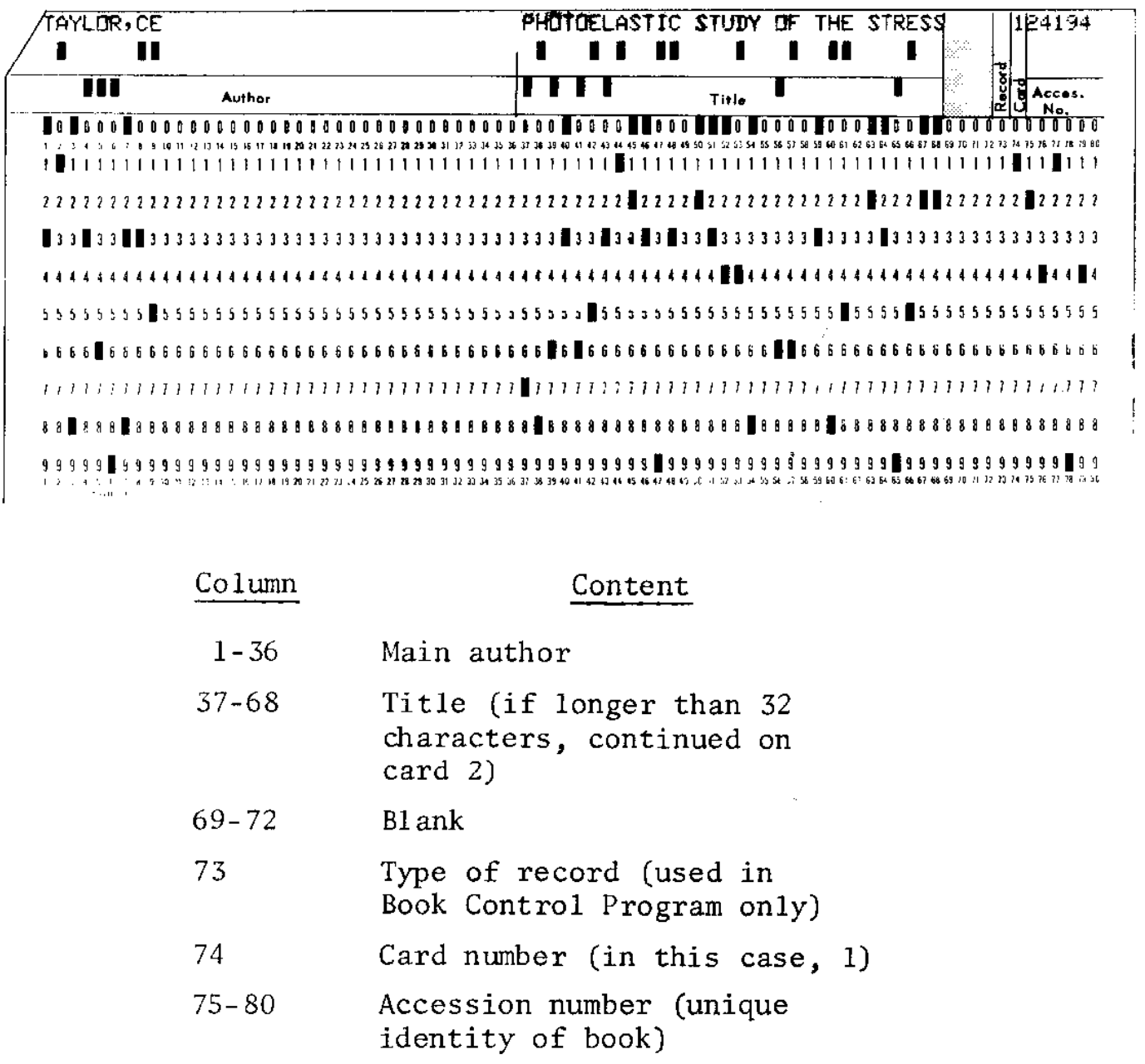

FIG. 6 BOOK CARD 1 


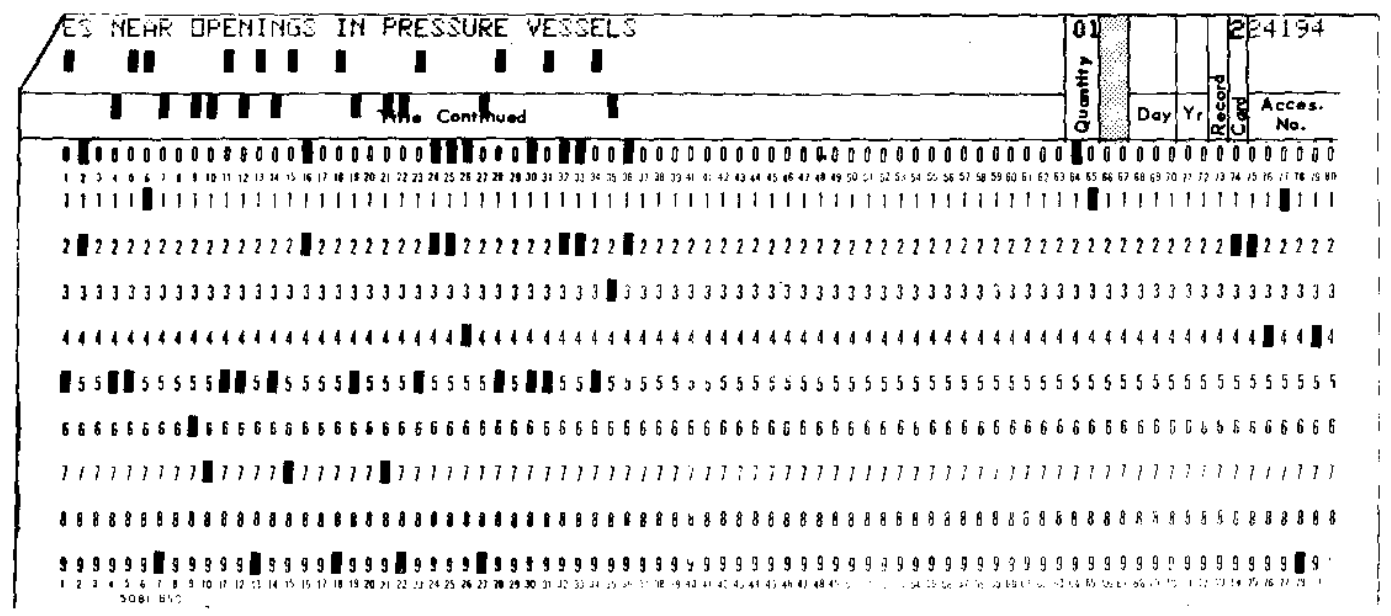

Column

Content

1 - 63 Continuation of title from Card 1

(Card 2 must always be submitted

for the Book Order Program even

though the title on Card 1 does

not exceed 32 characters).

64 - 65 Quantity of books ordered (used in

Book Order Program, data not stored permanently; leading zeros).

$66-72 \quad$ Bl ank

73 Type of record (used in Book Control Program only).

74 Card Number (in this case, 2).

$75-80 \quad$ Accession number

FIG. 7 BOOK CARD 2 


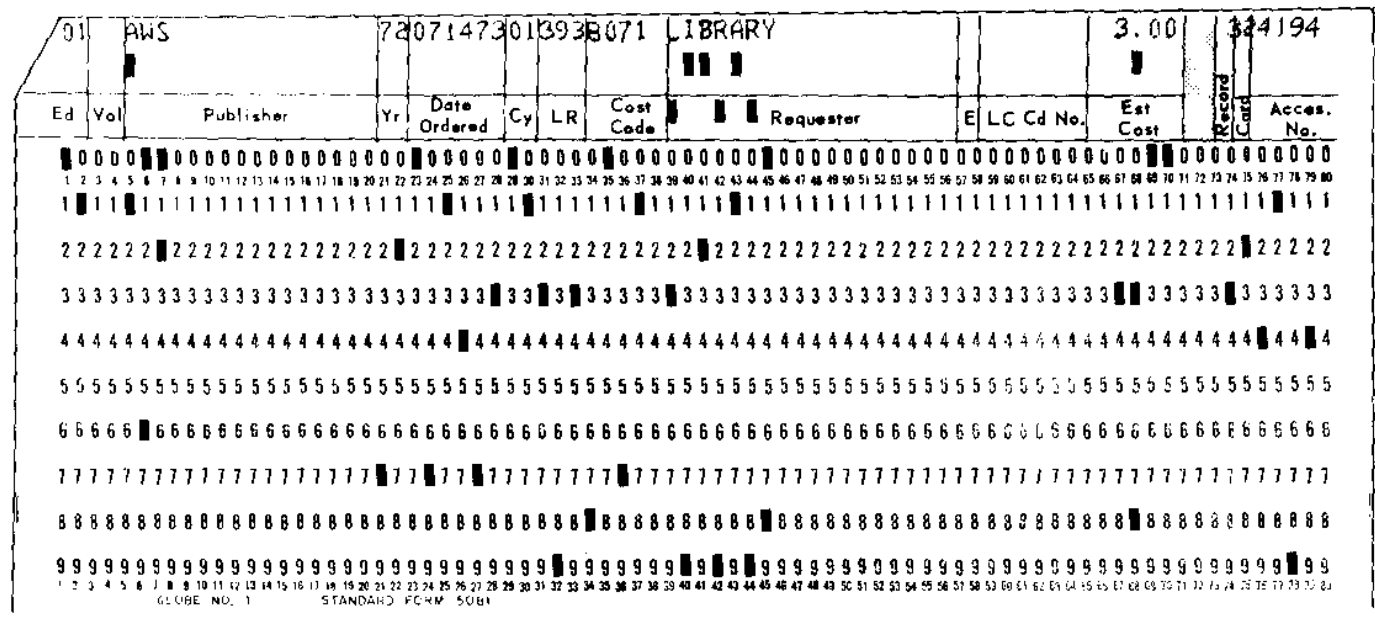

\begin{tabular}{|c|c|}
\hline Column & Content \\
\hline $1-2$ & Edition \\
\hline $3-4$ & Volume \\
\hline $5-20$ & Publisher \\
\hline $21-22$ & Year of publication \\
\hline $23-28$ & $\begin{array}{l}\text { Date book ordered (1eading } \\
\text { zeros) }\end{array}$ \\
\hline $29-30$ & $\begin{array}{l}\text { Copy number (indicates number } \\
\text { of copies in library's collect- } \\
\text { ion; leading zeros) }\end{array}$ \\
\hline $31-33$ & Transmittal Letter number \\
\hline $34-38$ & Cost code to which book charged \\
\hline $39-56$ & $\begin{array}{l}\text { Requester (an individual's } \\
\text { namc if book is desk copy; } \\
\text { "library" if book is cataloged } \\
\text { for the library's collection; } \\
\text { can be used later to indicate } \\
\text { "lost" or "surplus" items) }\end{array}$ \\
\hline 57 & $\begin{array}{l}\text { Expendable (term used for } \\
\text { accounting purposes) normally } \\
\text { blank. }\end{array}$ \\
\hline $58-64$ & Blank \\
\hline $65-70$ & $\begin{array}{l}\text { Estimated cost of book (data } \\
\text { not stored permanently; right } \\
\text { justified) }\end{array}$ \\
\hline $71-72$ & Blank \\
\hline 73 & $\begin{array}{l}\text { Type of record (used in Book } \\
\text { Control Program on } 1 y \text { ) }\end{array}$ \\
\hline 74 & $\begin{array}{l}\text { Card number (in this case, 3) } \\
\text { Accession number }\end{array}$ \\
\hline
\end{tabular}

FIG. 8 BOOK CARD 3 


\section{$\checkmark$}

22 


\section{APPENDIX B Master File for Book Control Program}

The Master File contains subject, series, and cross-reference lists for:

- Cataloged library materials

- Surplus and lost items

- Departmental or desk copies of books

- Annual bound volumes of periodicals

Even though the subject, series, and cross-reference lists are used differently and at different times, the program is written to treat the Master File as one sequential file. New data may be added, and data existing on the Master File may be altered or deleted.

\section{SUBJECT DATA INPUT}

Subject data consist of a five digit numeric code and a corresponding alphabetic prefix heading. These data are stored in card image form (Figure 9).

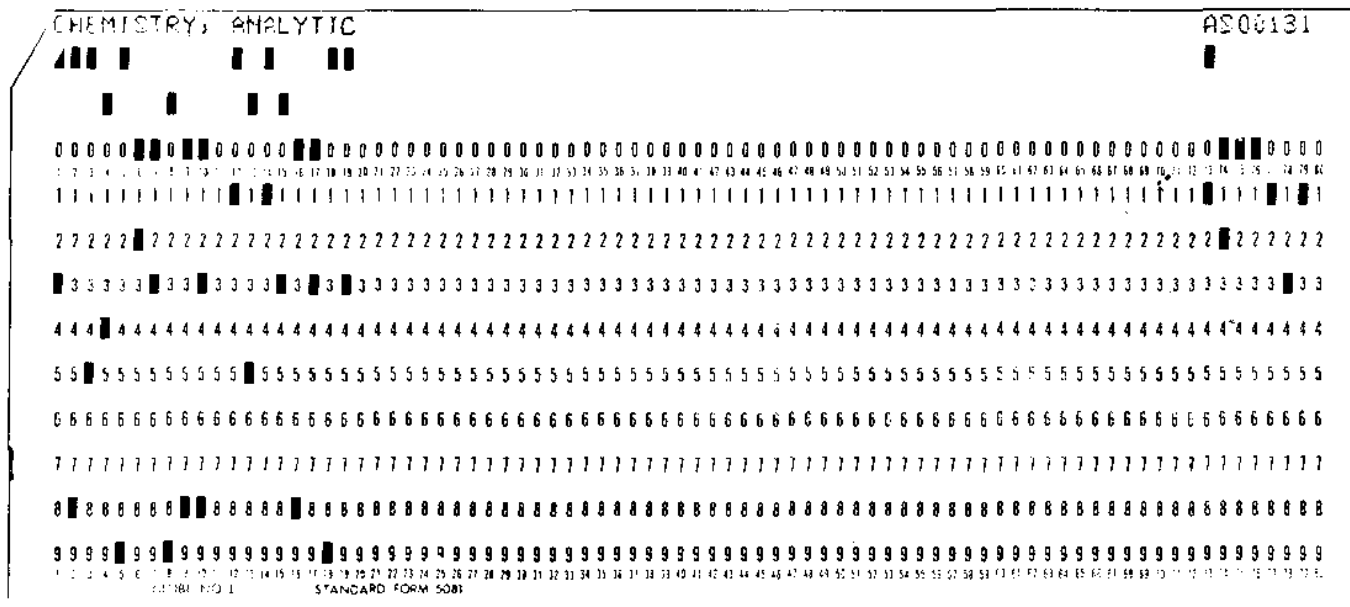

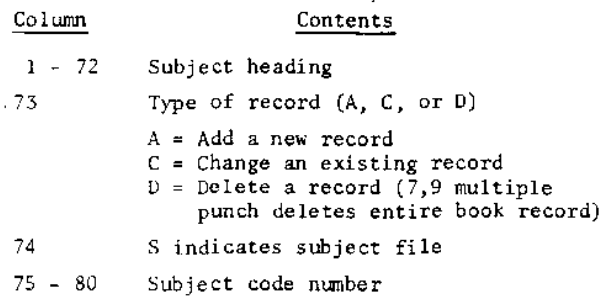

FIG. 9 SUBJECT INPUT CARD 


\section{SERIES DATA INPUT}

Series data consist of a five-digit numeric code and a corresponding alphabetic prefix heading. These data are stored in card image form (Figure 10).

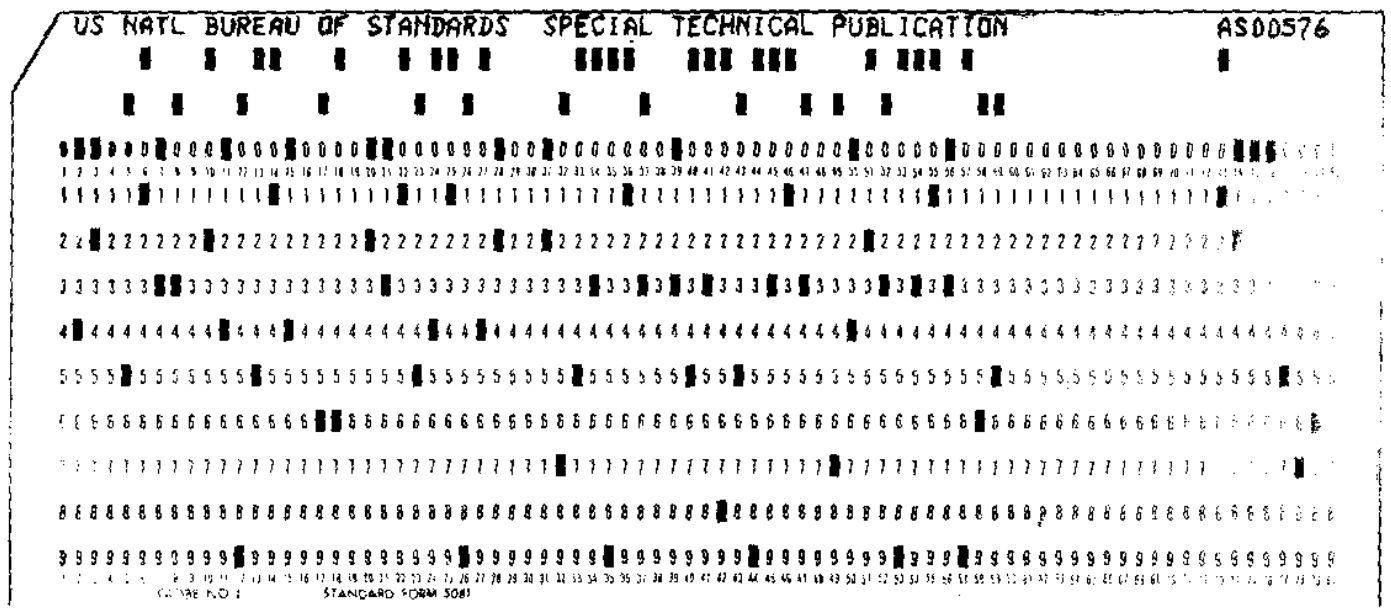

\begin{tabular}{ll} 
Column & \multicolumn{1}{c}{ Content } \\
1 & Blank (to differentiate Subject from Series) \\
$2-72$ & Series heading \\
73 & Type of record (A, C, or D - see Fig. 9) \\
74 & S (to indicate series file) \\
$75-80$ & Series code number
\end{tabular}

FIG. 10 SERIES INPUT CARD 
These data input "see" and "see also" references to the program. A subject cross-reference record consists of a fivedigit numeric code and a corresponding alphabetic prefix heading. This record is stored in card image form (Figure 11).

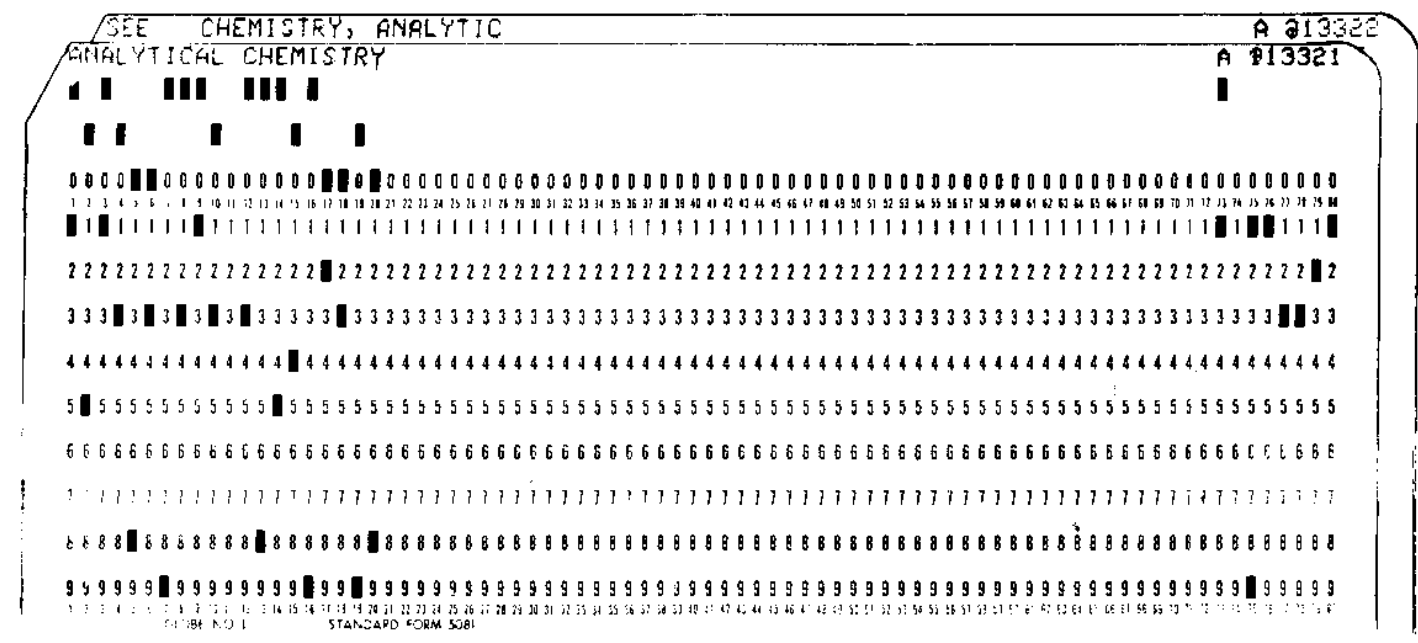

\begin{tabular}{ll} 
Column & \multicolumn{2}{c}{ Content } \\
$1-72$ & Cross-reference heading \\
73 & Type of record (A, C, or D - see Fig. 9) \\
74 & Blank \\
75 & 9,1 multiple punch \\
$76-79 \quad$ & Cross-reference code number \\
80 & 1 (to indicate "see from" reference) \\
& or 2 (to indicate "see" reference)
\end{tabular}

FIG. 11 SUBJECT CROSS-REFERENCE CARD 
The Master File also contains book information. As many as nine different card formats may be used. Cards 1 through 4 contain the primary information and are always necessary (Figures 6-8 and 12). Cards 5 through 8 contain secondary information such as subject codes and alternate title or author (Figures 13-16). Card 9 , the charge-out card, contains information pertaining to the loan of the book (Figure 17). Cards 5 through 9 are optional. It is not necessary that the card input be in order. Charge-out cards, deletion cards, change cards, and new-book cards can be submitted simultaneously and in any order.

Cards 1 through 3 were originally punched for the Book Order Program.

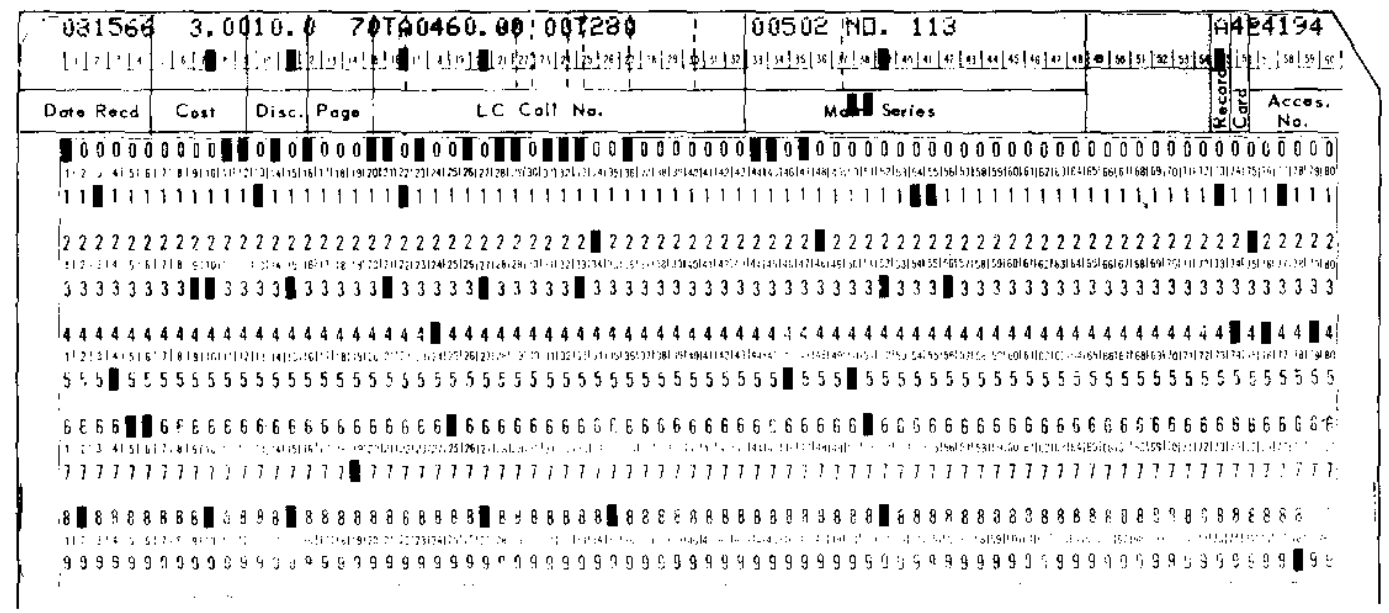
Column
Content
$1-6$
Date book received (leading zeros)
$7-12$
Price of book before discount (right justified)
$13-16$
Percent discount on price of book (leading zero)
$17-20$
Pagination (right justified)
$21-43$
Ca11 number (expanded beyond normal form) ${ }^{a}$

FIG. 12 BOOK CARD 4 (Primary Information) 


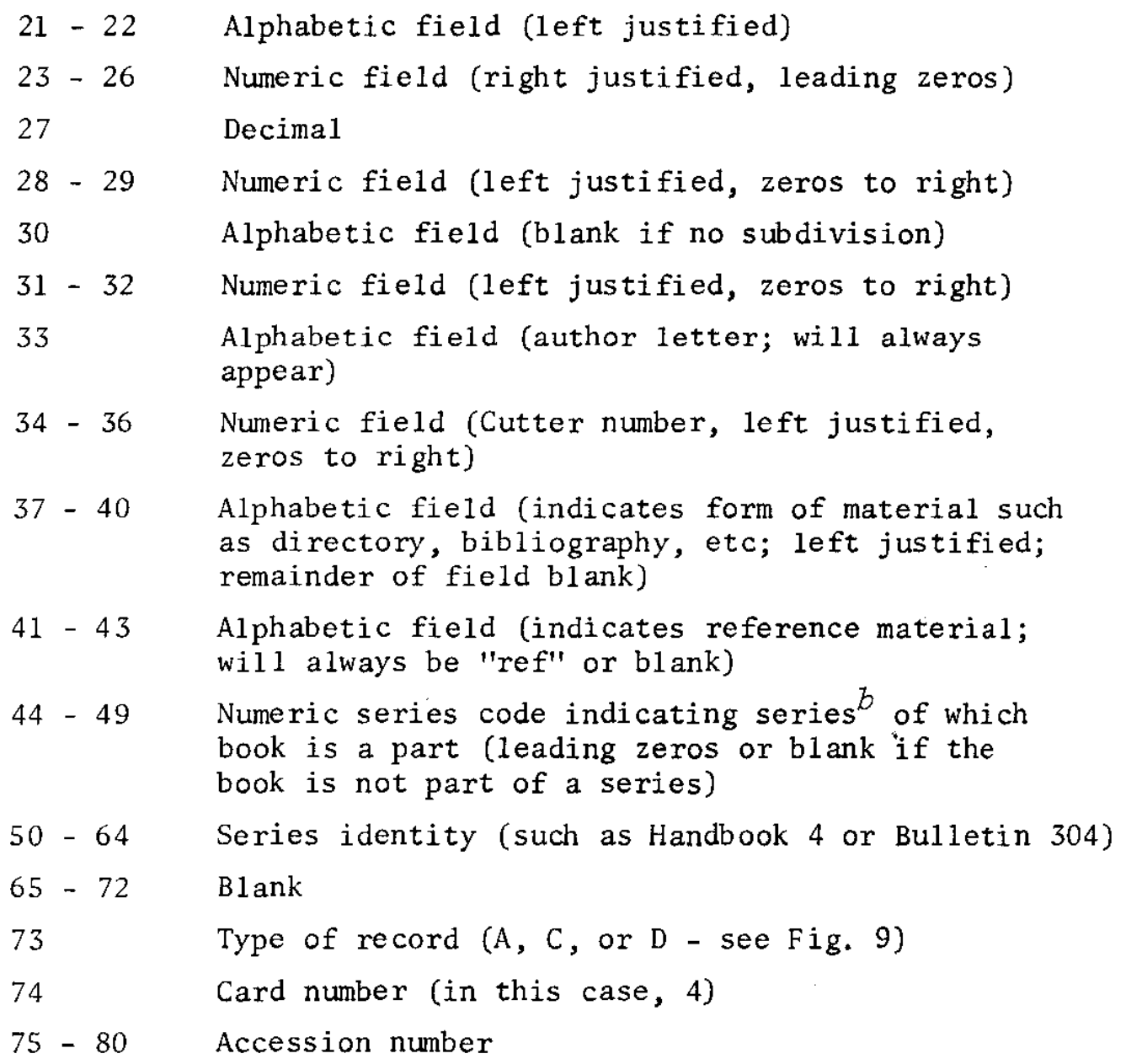

a. As indicated, the call number of a book is entered in expanded form to facilitate sorting. On a final printout, however, the call number will appear in its normal form.

b. A series of publications issued with some regularity usually by the same publisher and with related subject matter, formats, etc.

FIG. 12 BOOK CARD 4 (Continued) 


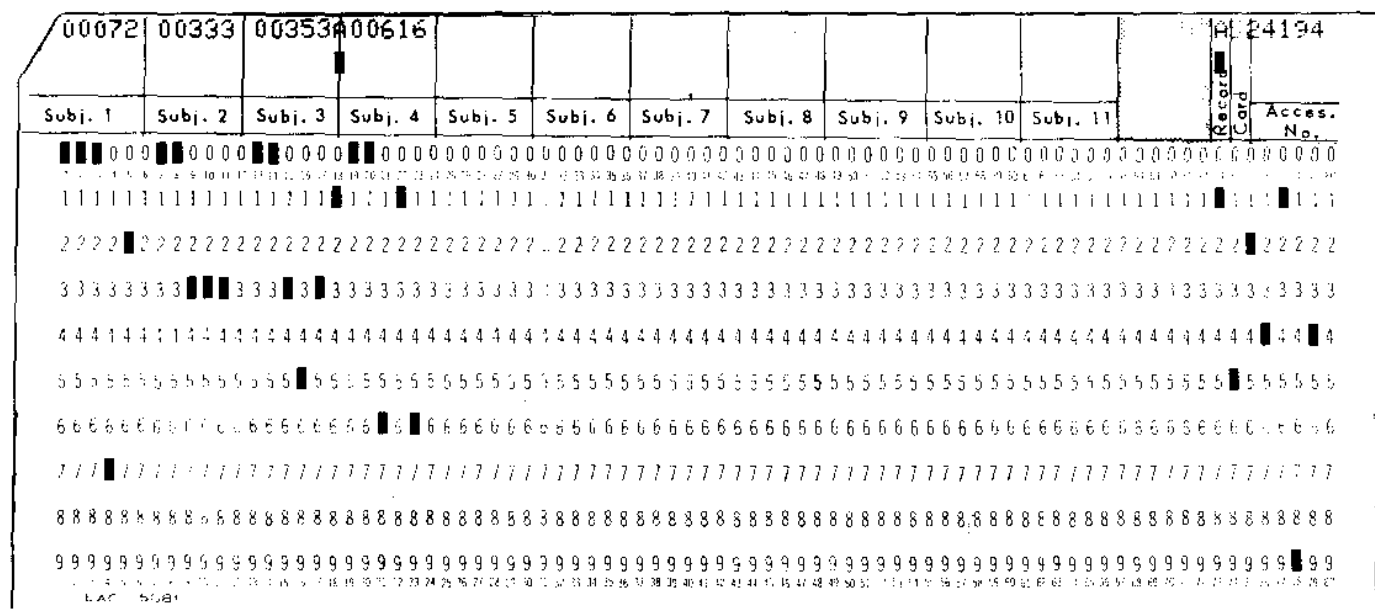

Column

Content

1 - 666 column subject codes for 11 subjects. Subject codes are 5-digit numbers (rightjustified with leading zeros) and an alphabetic character or blank in the sixth column.

$67-72 \quad$ B 1 ank

73 Type of record (A, C, or D - see Fig. 9)

74 Card number (in this case,

$75-80 \quad$ Accession number

FIG. 13 BOOK CARD 5 (Numeric Codes for Subject Headings) 


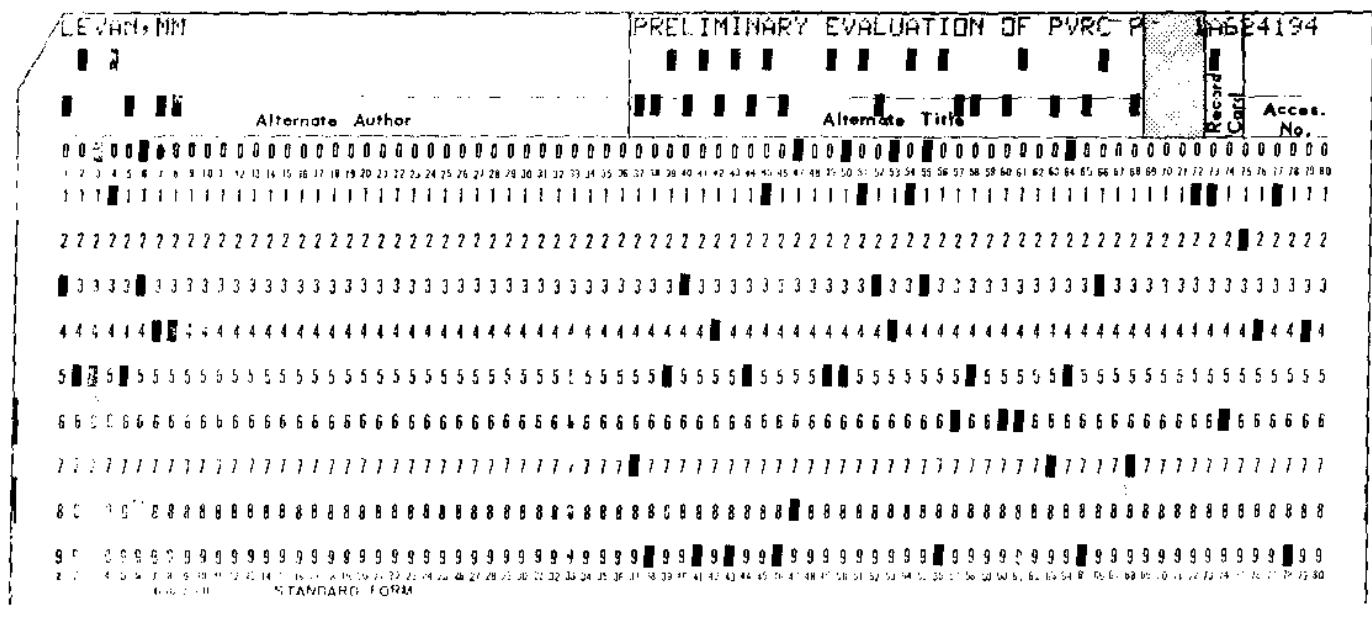

\begin{tabular}{ll} 
Column & \multicolumn{2}{c}{ Content } \\
$1-36$ & Joint author or added author entries \\
$37-68$ & $\begin{array}{l}\text { Added title entry (may be continued } \\
\text { on card } 7)\end{array}$ \\
$69-71$ & B1ank \\
72 & $\begin{array}{l}1 \text { (if 1st added entry; 2 if second; } \\
3 \text { if third) }\end{array}$ \\
73 & Type of record (A, C, or D - see \\
74 & Fig. 9) \\
$75-80$ & Accession number number (in this case, 6)
\end{tabular}

a. As many as three additional authors and titles may be added. For each additional title or author, an extra card must be punched.

FIG. 14 BO0K CARD $6 \begin{aligned} & \text { (Secondary } \\ & \text { Authors and Titles) }\end{aligned}$ 


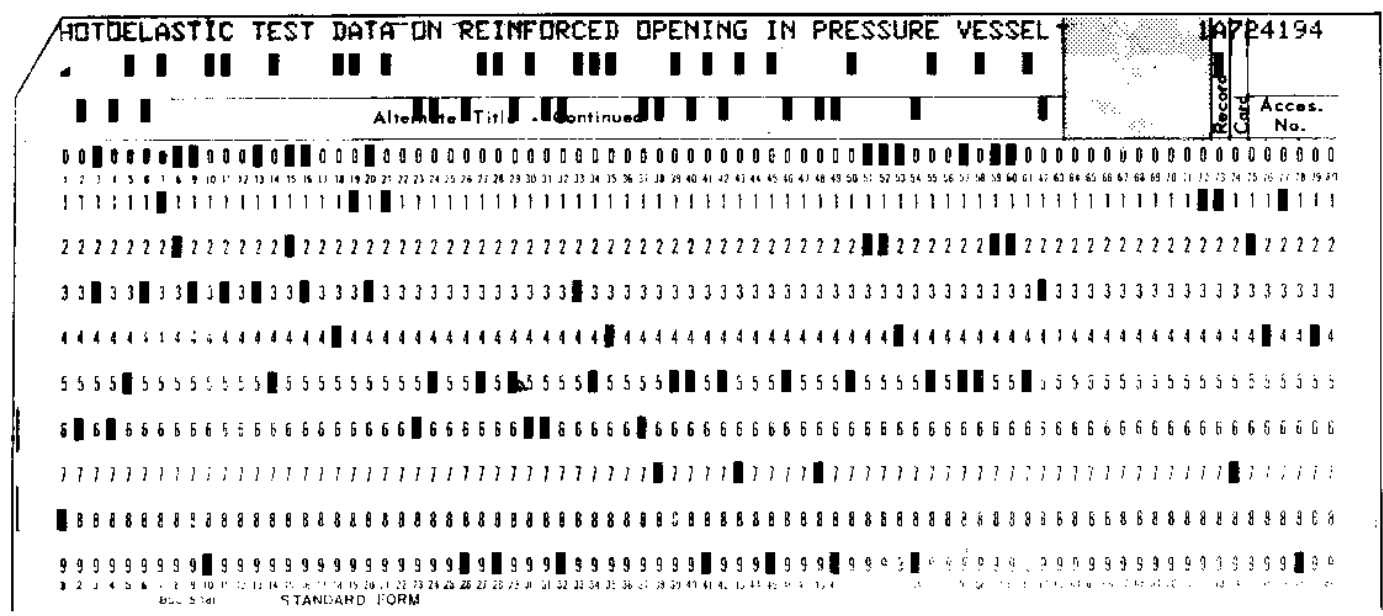

\begin{tabular}{ll} 
Column & \multicolumn{2}{c}{ Content } \\
$1-63$ & $\begin{array}{l}\text { Added title entry (continued from } \\
\text { card 6) }\end{array}$ \\
$64-71$ & $\begin{array}{l}\text { Blank } \\
72\end{array}$ \\
& $\begin{array}{l}\text { 3 if } \text { if 3rd) } \\
\text { Type of record (A, C, or D - see }\end{array}$ \\
73 & Fig. 9) \\
74 & Card number (in this case, 7) \\
$75-80$ & Accession number
\end{tabular}

a. If there are no added author or title entries, Cards 6 and 7 are not necessary.

FIG. 15 BOOK CARD 7 (Extended Title - if needed) 


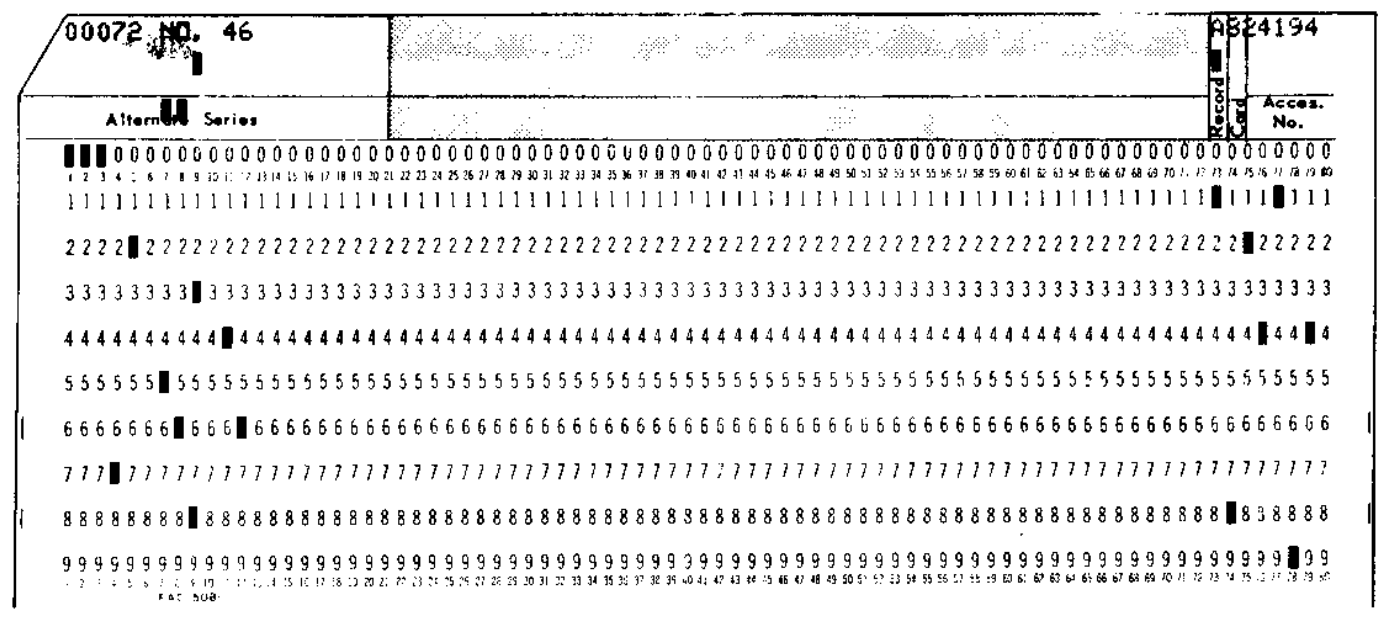

\begin{tabular}{|c|c|}
\hline Column & Content \\
\hline $1-6$ & $\begin{array}{l}\text { First added series code (leading } \\
\text { zeros) }\end{array}$ \\
\hline $7-21$ & First added series identity ${ }^{a}$ \\
\hline $22-27$ & $\begin{array}{l}\text { Second added series code (1eading } \\
\text { zeros) }\end{array}$ \\
\hline $28-42$ & Second added series identity \\
\hline $43-48$ & $\begin{array}{l}\text { Third added series code (leading } \\
\text { zeros) }\end{array}$ \\
\hline $49-63$ & Third added series identity \\
\hline $64-72$ & Bl ank \\
\hline 73 & $\begin{array}{l}\text { Type of record (A, C, or D - see } \\
\text { Fig. 9) }\end{array}$ \\
\hline 74 & Card number (in this case, 8) \\
\hline $75-80$ & Accession number \\
\hline
\end{tabular}

a. As many as three added series per book record may be submitted. If there are no added series entries, this card may be omitted.

FIG. 16 BOOK CARD 8 (Additional Series) 


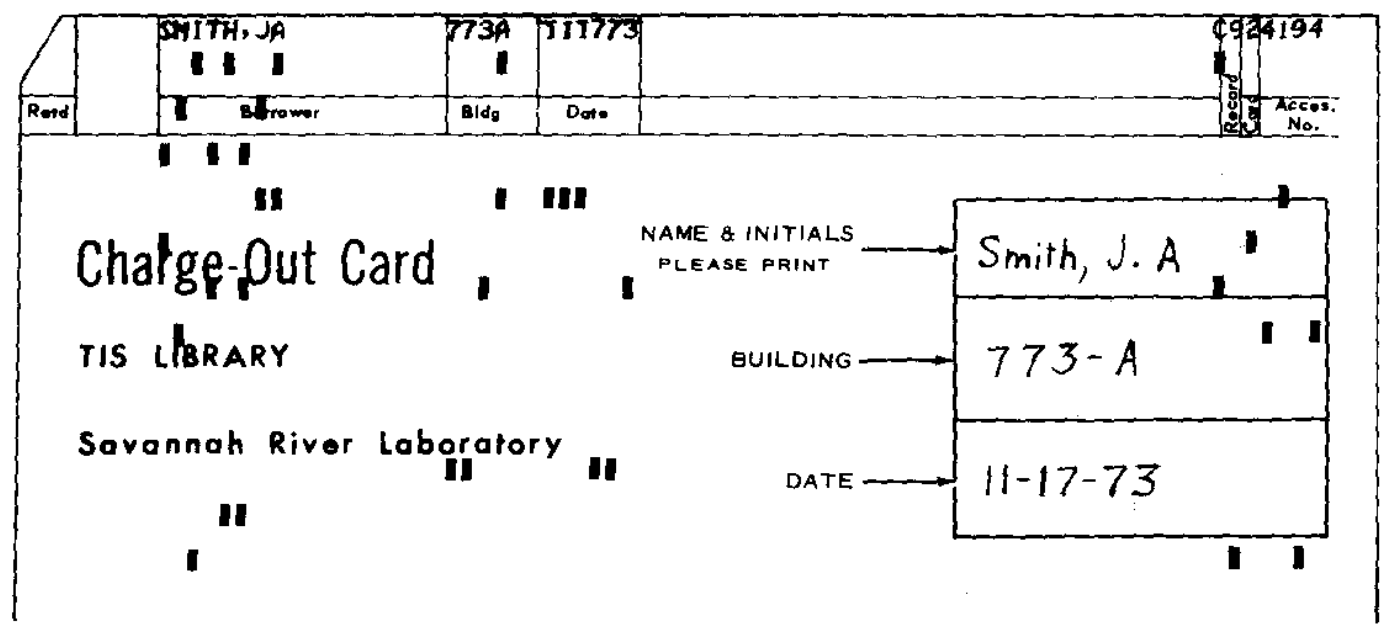

\begin{tabular}{ll} 
Column & \multicolumn{1}{c}{ Content } \\
1 & $\begin{array}{l}\text { Blank if book presently loaned; } \\
\text { "R" if book returned } \\
2-6\end{array} \quad$ Blank \\
$7-24$ & Borrower's name \\
$25-30$ & Borrower's address \\
$31-36$ & Date borrowed \\
$37-72$ & Blank \\
73 & Type of record (always C; prepunched) \\
74 & Card number (in this case, 9) \\
$75-80$ & Accession number
\end{tabular}

FIG. 17 BOOK CARD 9 (Charge-Out) 
To add a new-book record to the Master File only Cards 1 through 4 are necessary. Card 2 can be deleted from the book order deck if the title is complete on Card 1.

To update an existing book record, a change card is necessary. The type of record code is always $C$. The card number is the same as for input for a new book record. Only the card containing the field to be changed is submitted. For example, to correct the main author entry, the following card (Figure 18) must be submitted.

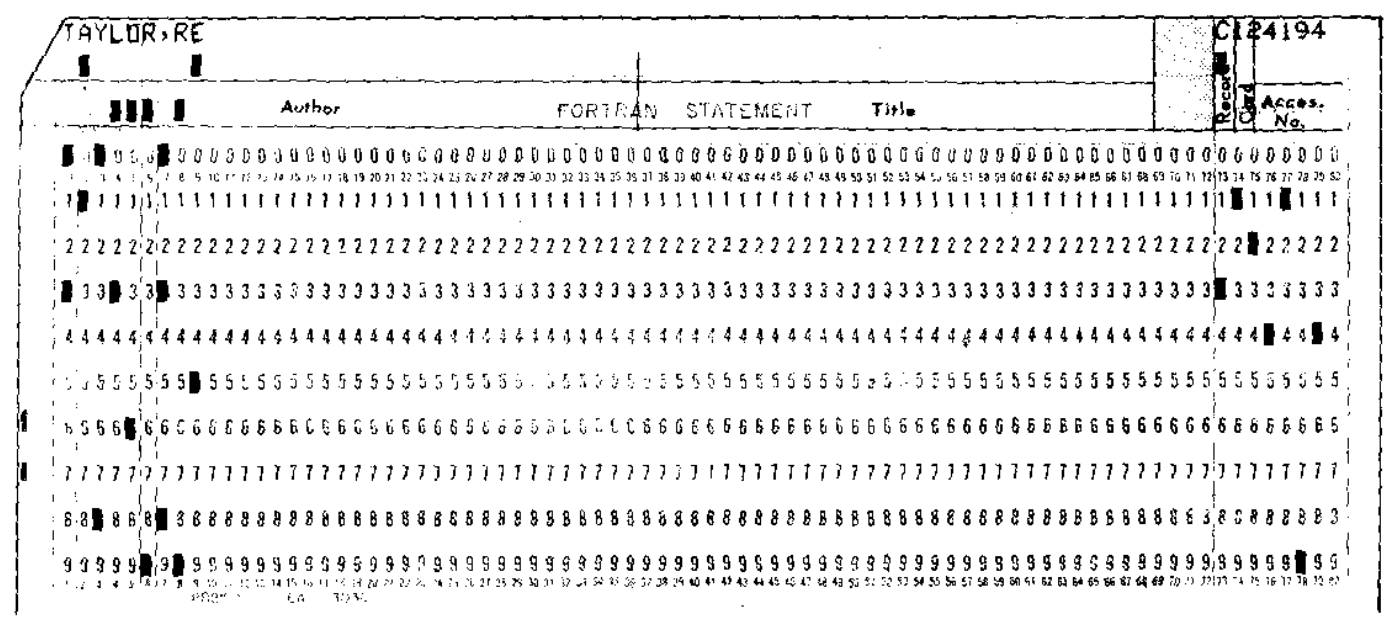

FIG. 18 CHANGE CARD FORMAT (Update or Correction) 


\section{DELETING BOOK DATA}

To delete a complete book record, a punched card containing only the accession number and the type of record code is submitted (Figure 19).

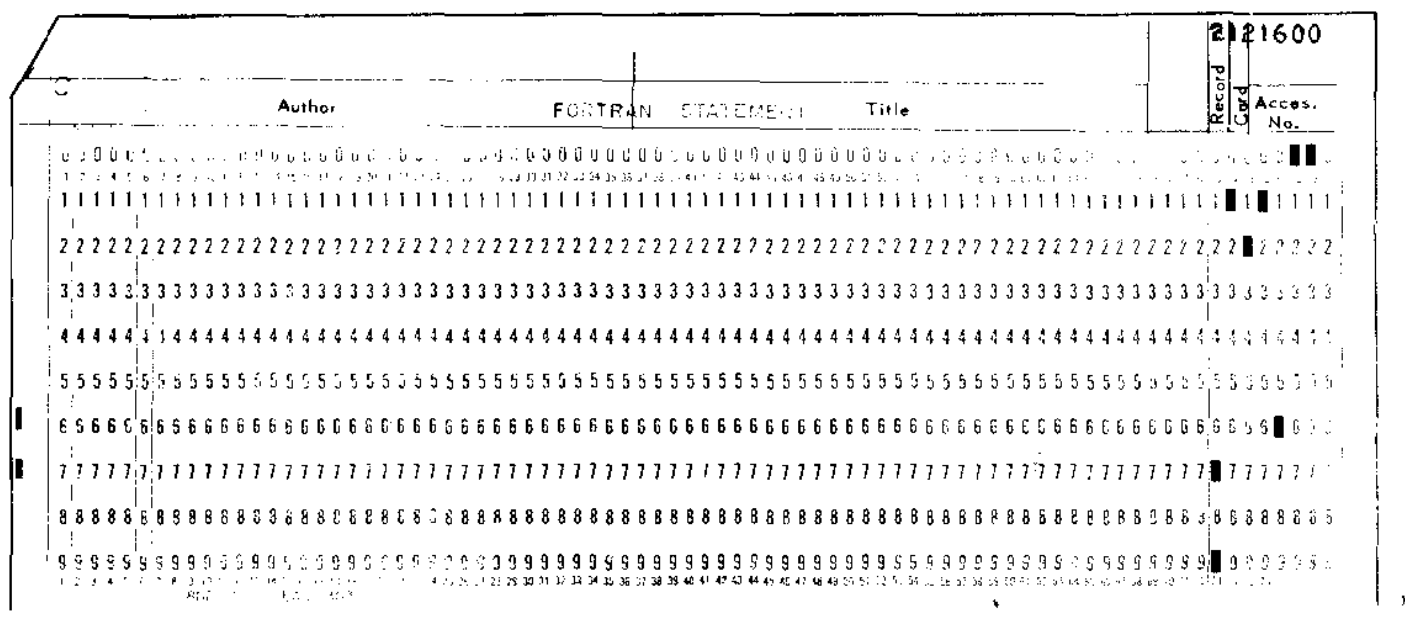

\begin{tabular}{ll} 
Column & \multicolumn{1}{c}{ Content } \\
$1-72$ & $\begin{array}{l}\text { Blank } \\
73\end{array}$ \\
& $\begin{array}{l}\text { Type of record (a 7,9 multiple } \\
\text { punch indicates deletion of whole } \\
\text { book record) }\end{array}$ \\
74 & $\begin{array}{l}\text { Card number (cards 1 through 9 could } \\
\text { be used; however, for convenience, } \\
\text { card 1 is almost always shown here) }\end{array}$ \\
$75-80$ & $\begin{array}{l}\text { Accession number }\end{array}$
\end{tabular}

FIG. 19 BOOK DELETION FORMAT 
To delete one card image of a book record, a punched card containing the accession number, card number, and type of record code is submitted. For example, the card below (Figure 20) will delete the card image for a Card 6 .

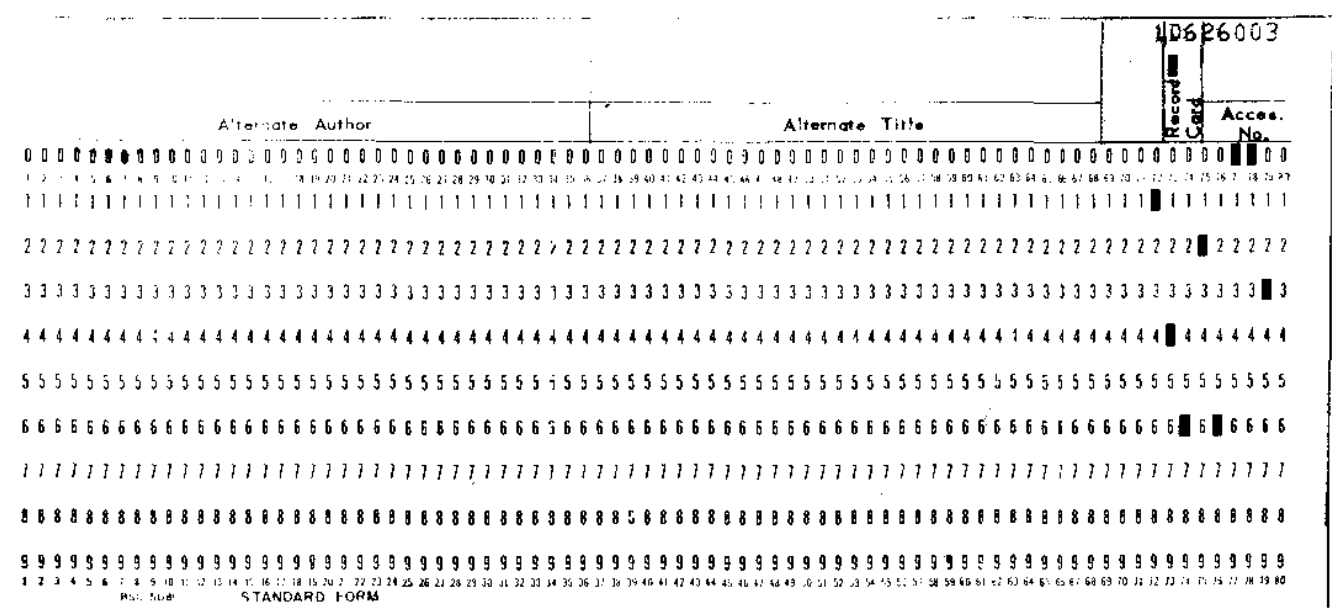

FIG. 20 CARD IMAGE DELETION FORMAT 
REPORT REQUEST CARD

To receive any of the report options the card shown in Figure 21 must appear first in the request deck.

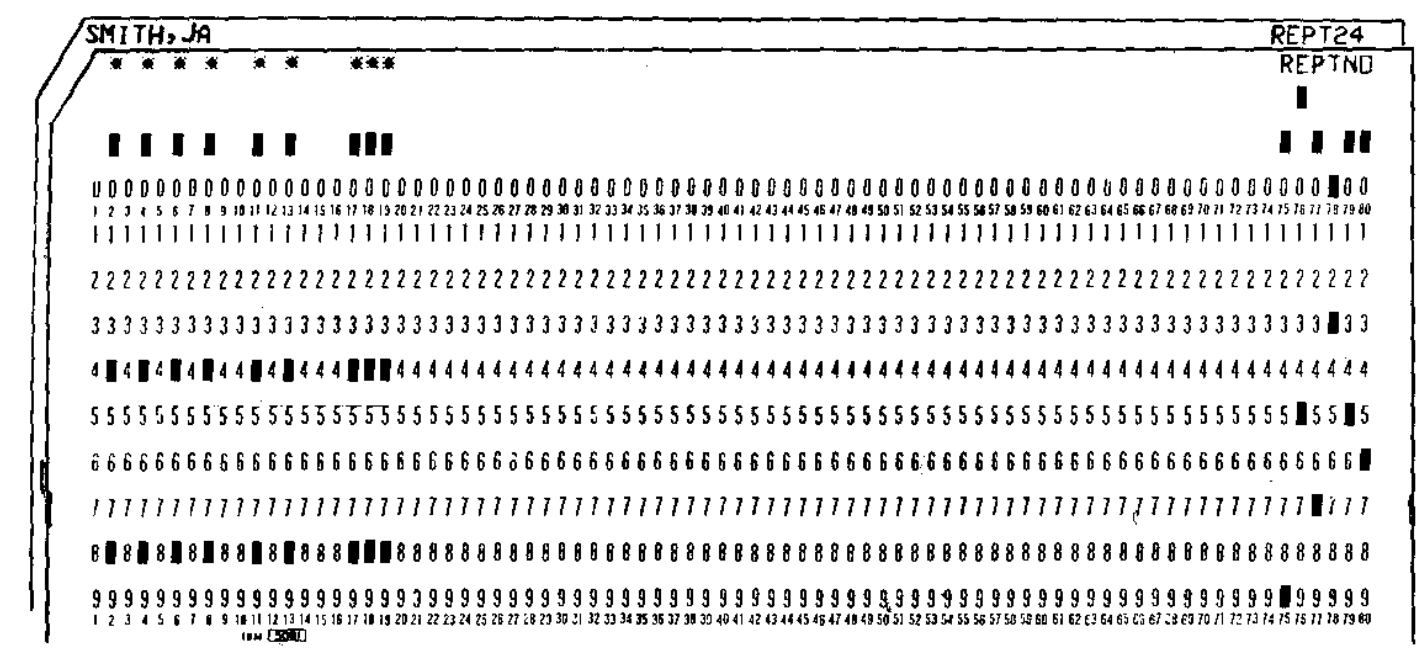

\begin{tabular}{ll} 
Column & \multicolumn{1}{c}{ Content } \\
$1-29$ & $\begin{array}{l}\text { Asterisks are punched in each column } \\
\text { whose number corresponds to the code } \\
\text { number of the reports requested. (Re- } \\
\text { fer to Table I and Figure 5.) }\end{array}$ \\
$30-74$ & Blank \\
$75-80$ & REPTNO
\end{tabular}

FIG. 21 REPORT REQUEST CARD 
If Report Codes 24, 25, or 27 are requested, additional data cards must be entered. To receive Report Code 24 (all books loaned to a particular individual) the card shown in Figure 22 must be entered indicating the name of the individual whose book listing is desired.

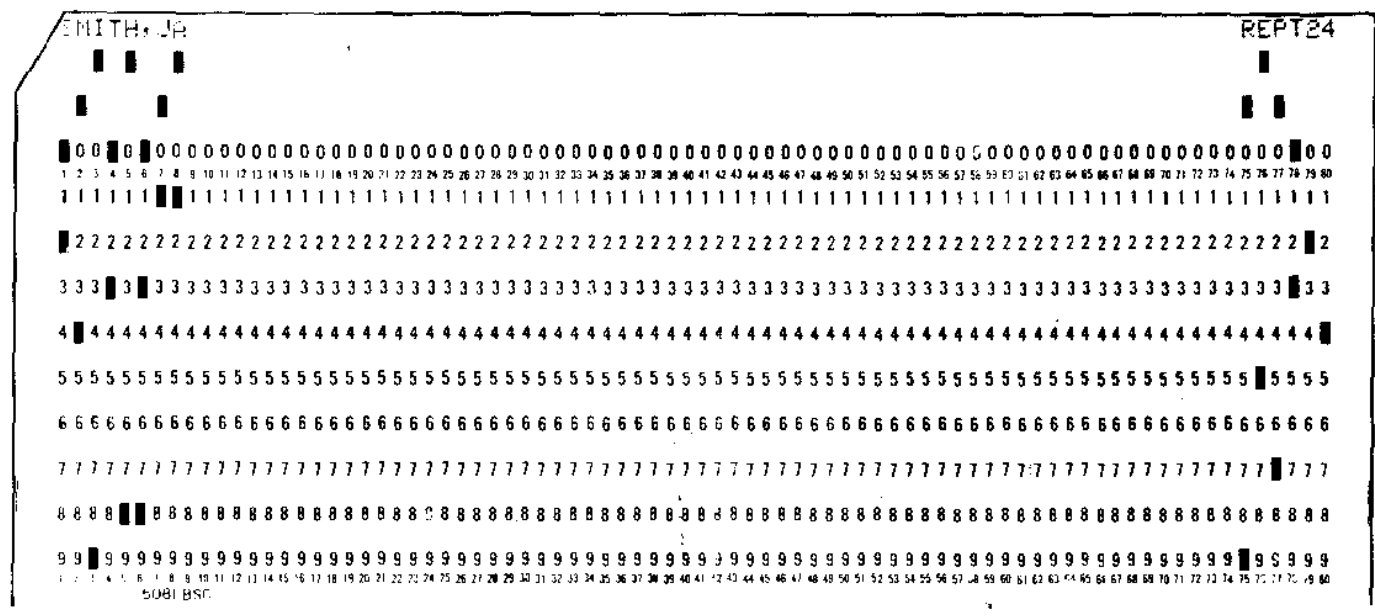

$\begin{aligned} \text { Column } & \text { Content } \\ 1-18 & \text { Name of requester or borrower } \\ 19-74 & \text { Blank } \\ 76-80 & \text { REPT24 }\end{aligned}$

FIG. 22 REQUEST CARD FOR REPORT CODE 24 (A)1 Books Charged to an Individual) 
To secure Report Code 25 (Recall notices) the loan cards (Figure 23) are sorted and the deck fed to the computer. No new cards need to be punched.

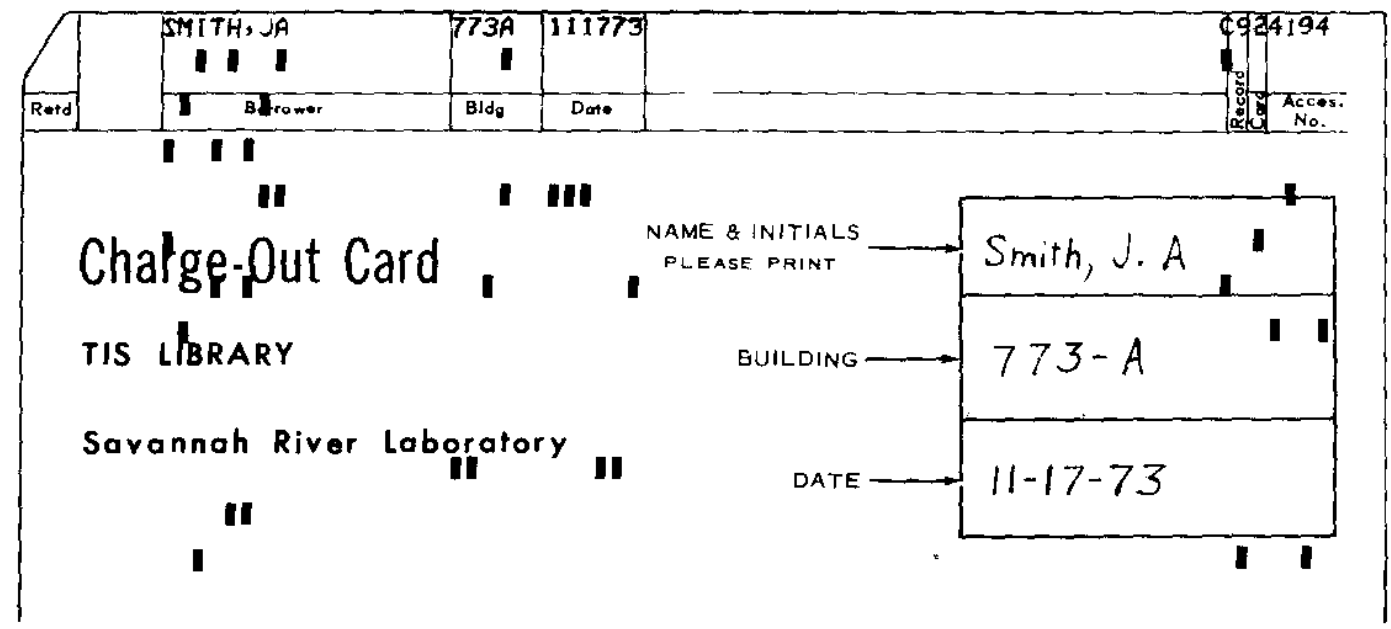

FIG. 23 LOAN CARD SUBMITTED FOR REPORT CODE 25 (RecalT Notices) 
To receive a printout of all books cataloged under a particular subject (Report Code 27), the subject codes must be punched and submitted as shown in Figure 24 .

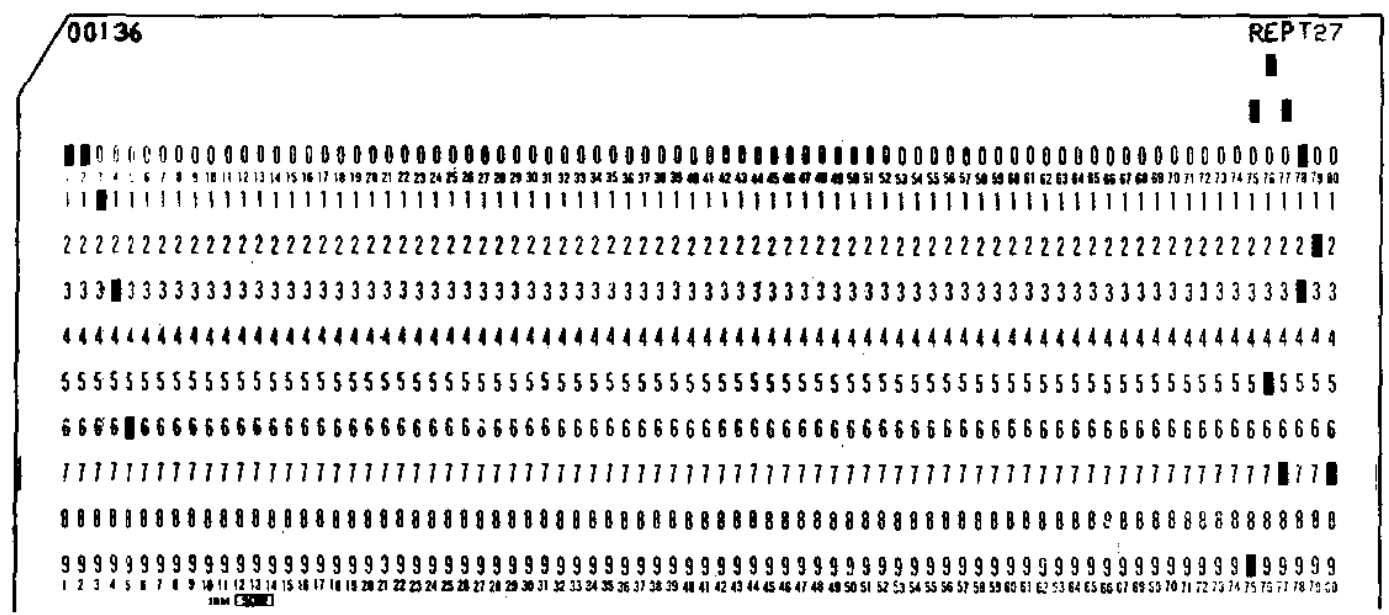

\begin{aligned} Column & \multicolumn{2}{c}{ Content } \\ $1-6 &$ Subject code number \\ $7-74 &$ B1ank \\ $75-80 &$ REPT27 \end{aligned}

FIG. 24 REQUEST CARD FOR REPORT CODE 27 (AII Books Cataloged under a Single Subject) 
Figure 25 shows how the request options card for Report Code 27 should be arranged. Request option cards for Report Codes 24 and 25 are arranged similarly.

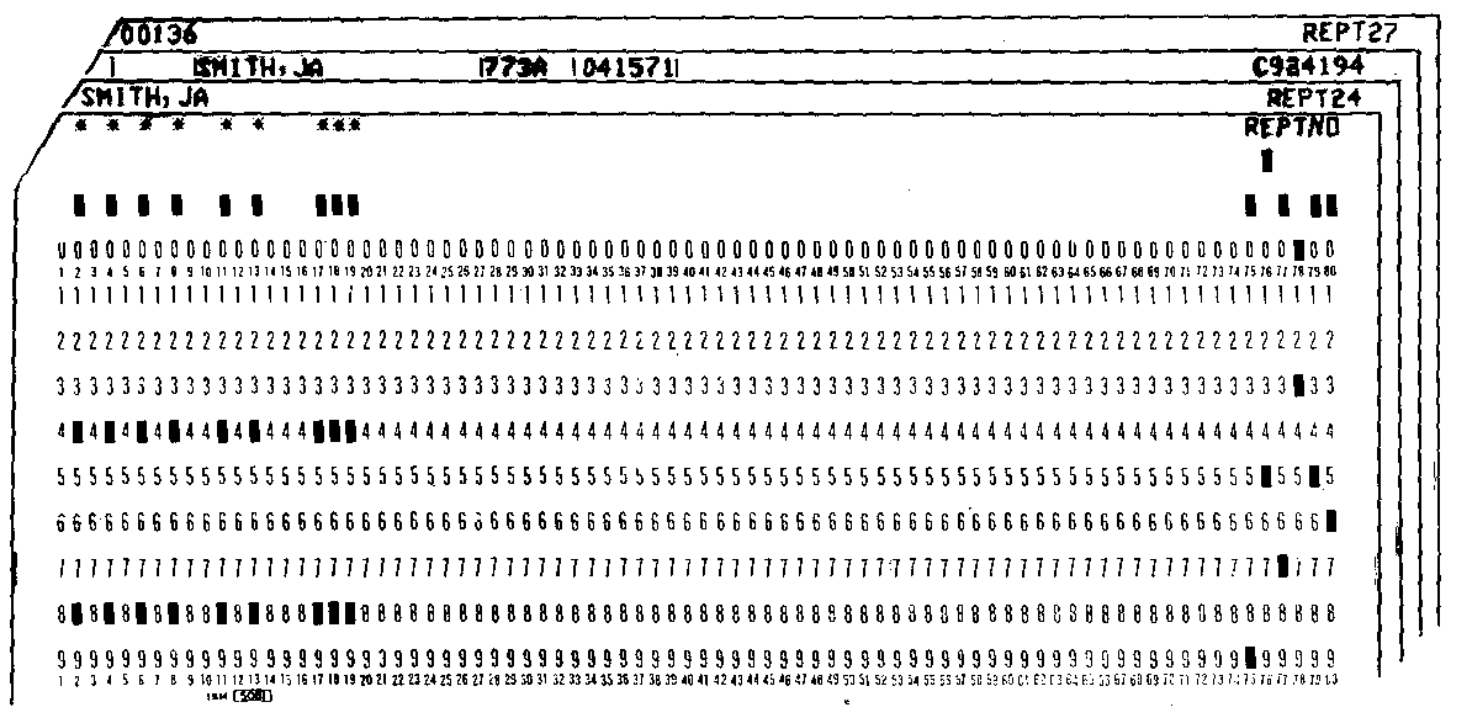

FIG. 25 REPORT REQUEST DECK 


\section{INITIAL SCRUB (Step 1)}

The Initial Scrub Program (Figure 26) transfers all update dati (new data, changes, and deletions) from punched cards to a Data Set Work File. At the same time the program "scrubs" the input data for errors, such as an incorrect card or record number.

Input to the Initial Scrub Program are punched cards containing all update data for the Master File. This includes additions, corrections, and deletions for subject and series, subject crossreferences, and book data. There is no limit on the number of cards that can be entered. They are submitted as a card deck and in any order.

Output from the Initial Scrub Program is a Data Set Work File containing the card images of the input data cards, excluding any which were deleted by the scrub. A printout listing additions, changes, and errors (Appendix D) found by the scrub routine is also generated by Step 1 .

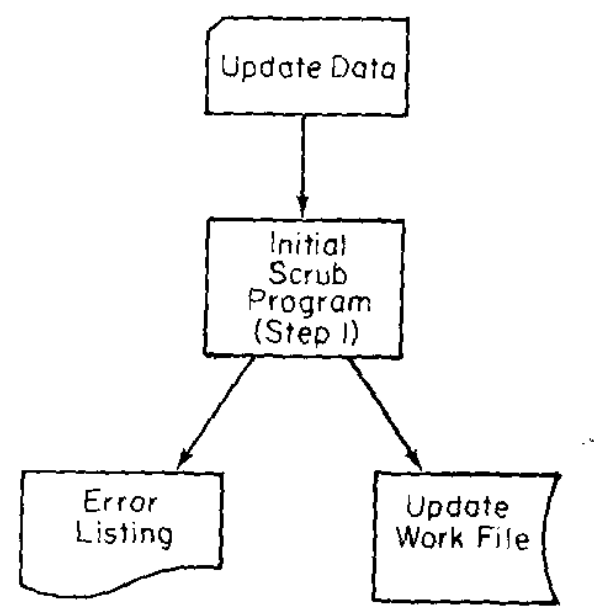

FIG. 26 FLOWCHART FOR INITIAL SCRUB PROGRAM 


\section{CARD IMAGE SORT PROGRAl! (Step 2)}

The Card Image Sort Program performs a major sort by accession number, and secondary sorts by record type, card number, and then an added entry number. Control information for this sort is supplied to the Operating System/360 Sort/Merge Program.

Input is the Data Set Work File from Step 1.

Output is the sorted data on a Data Set Work File. This file is one source of input for Step 3 (Figure 27).

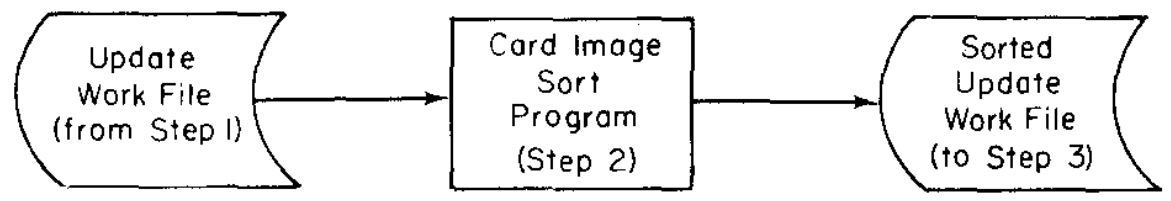

FIG. 27 FLOWCHART FOR CARD IMAGE SORT PROGRAM

UPDATE AND REPORT PROGRAM (STEP 3)

The Update and Report Program (Figure 28) performs five main functions:

1. Adds a new record to the Master File

2. Changes an existing record in the Master File.

3. Deletes an existing record on the Master File.

4. Identifies book records relevant to the report requests received.

5. Stores pertinent data in formats designed to facilitate sorting.

Update Functions

The update function to be performed is determined by the record code punched in each card (see card formats).

The first part of the Master file to be updated is the series and subject data. Library personnel have the option of adding, changing, or deleting any subject or series data. 
The Master File entries are updated sequentially on the basis of subject or series code numbers. Because the subject and series file is too large to warrant storing all of it in the memory core, a direct access method is used to perform the operation of retrieving the proper heading for a numeric code.

As the Master File is being updated, each subject or series entry is written on a temporary file. When all entries have been processed, the temporary file is written on a direct access device utilizing relative organization. This new Direct Access File is now used throughout Step 3 (Update and Report Program) as a relatively organized Random Access File to replace subject and series codes with their corresponding headings.

The next portion of the Master File, the subject cross-reference data, is also updated sequentially according to code number. If Report Code 14 is requested (Table I), the cross-reference data are written on a temporary file to be passed as input to Step 5 (Printout Program). This temporary file is generated as the Cross-Reference Master File is updated.

The final portion of the Master File to be updated is the book information. Here again data may be added, changed, or deleted. The Update and Report Program (Step 3) stores the data (as few as 3 or as many as 13 punched cards per book record) into a data bank as card images. The program ascertains for each new book record that the correct number of cards has been submitted in Step 1 and that the accession number has not been assigned previously to another book. If one or more of the three cards containing primary information is omitted (Cards 1, 3, and 4), an error message is generated, and the book is not added to the Master File.

Once a book has been added to the Master File; any additional data must be submitted as a "change" record. To change data in an existing book record, only those cards containing the fields which are to undergo change are submitted. The Update and Report Program matches the accession number of the change card with the accession number of an existing card image. Each field of the change card is checked to see if it is blank. The contents of a nonblank field replace the contents of a corresponding field in the existing record.

To blank out a call number, series, subject, or the term "expendable," an asterisk is punched in the first column of that data field. The program checks for an asterisk and sets the corresponding field to blanks. 
The accession number of a book can never be changed. If attempted, however, an error message is generated, and the complete book record must be deleted and re-added with the corrected accession number.

To delete an existing card image in a book record, the Update and Report Program matches the accession number and the card number of the change card with an existing card image. The matching record remains on the old Master file and is not transferred to the new Master File. Similarly, a complete book record may be deleted from the Master File with only the accession number of the update card being matched with the accession number of an existing book record. AlI card images having this accession number are deleted from the Master File.

\section{Report Functions}

Reports, or listings, are requested by use of a Report Code (Table I). Each complete book record is examined to see if it is relevant to the requested reports; if so, it is written in a work data set in a format that will facilitate sorting in the Report Sort Program (Step 4).

In a cumulative printout, the program first examines a record to see if it is pertinent to the report requested and then determines if the book is already on a corresponding master report. In a master printout, the program determines only if the book record is pertinent to the report requested.

As a book is added to a master report, the book record is flagged to indicate it should not appear on any subsequent corresponding cumulative printouts. Library personnel request cumulative reports as supplements to a master printout. When the supplements become too large and cumbersome, a new master printout is requested.

Input for Update and Report Program is:

1) old Master File

2) Request Option (Report Code) punched card

3) sorted update work file generated in Step 2 
Output for this program is
1) new Master File
2) report work file
3) cross-reference file
4) input and error listing

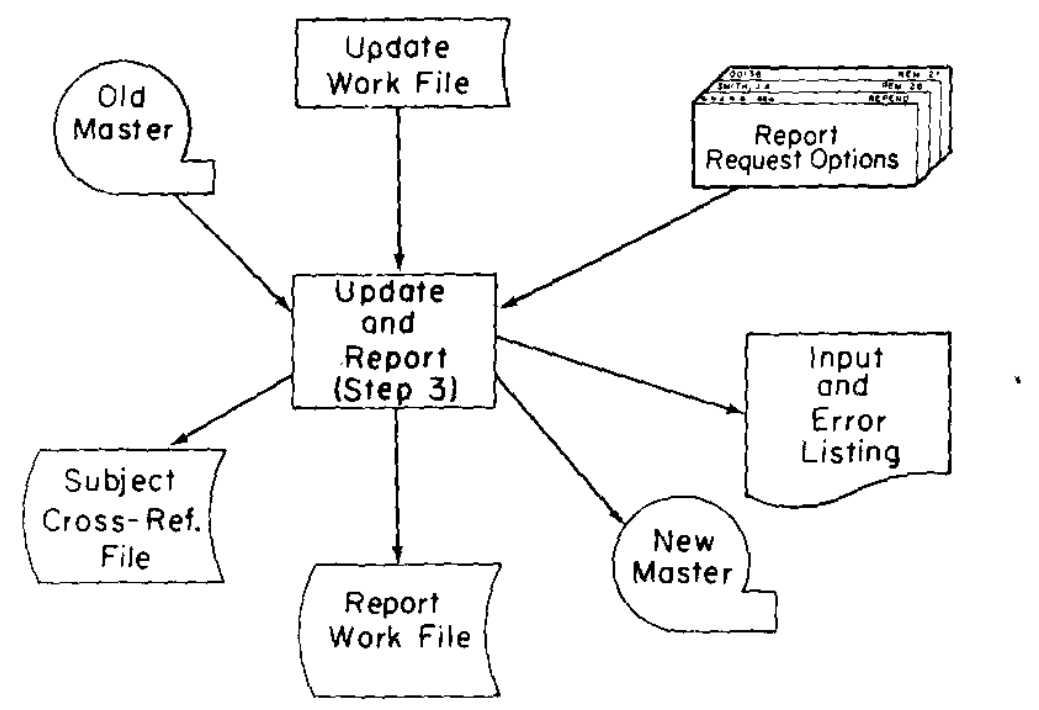

FIG. 28 REPORT FLOW CHART

\section{REPORT SORT PROGRAM (STEP 4)}

The Report Sort Program uses the Operating/360 Sort/Merge Program.

Input is the work file containing report information produced in Step 3.

Output is the sorted work file to be used as input to step 5 .

This program sorts the information into the selected Report Codes ( 1 to 29 - see Table I and Figure 5). 


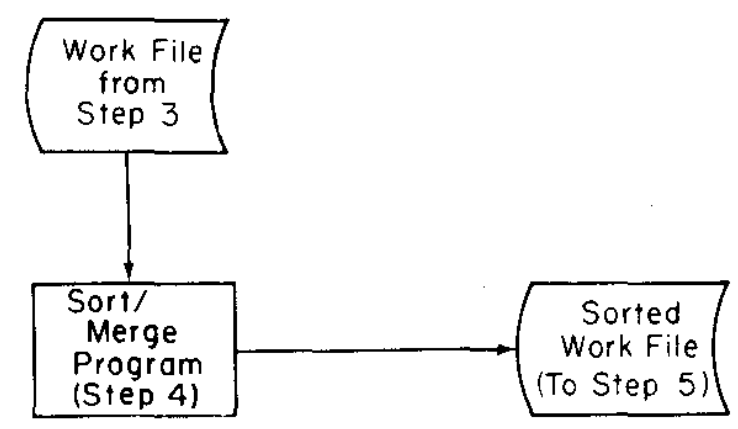

FIG. 29 FLOWCHART FOR REPORT SORT PROGRAM

\section{PRINTOUT PROGRAM (STEP 5)}

The Printout Program arranges and lists the information from the sorted report work file into proper formats for the requested report codes (Figure 30 ).

Input is the sorted work file generated in step 4 and the temporary cross-reference file generated in step 3 .

Output is the report listings as requested by designated report codes.

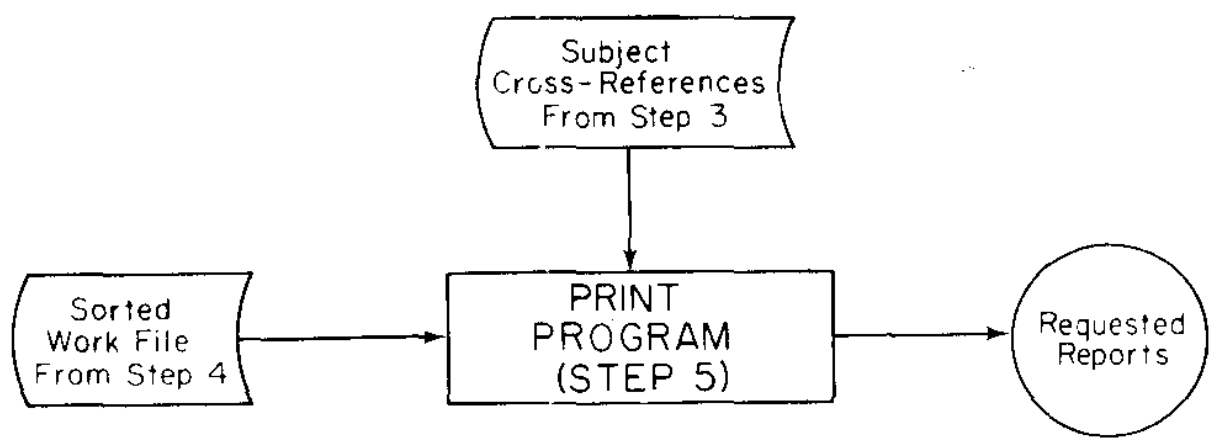

FIG. 30 FLOWCHART FOR PRINT PROGRAM 
Examples of each type of listing obtainable from the Printout Program appear in Figures 31 through 49.

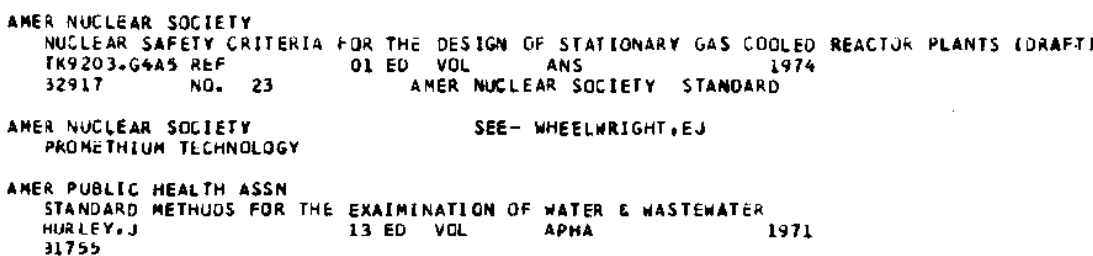

FIG. 31 ALL BOOKS BY AUTHOR, TITLE, AND ACCESSION NUMBER (Report Codes 1 and 2)

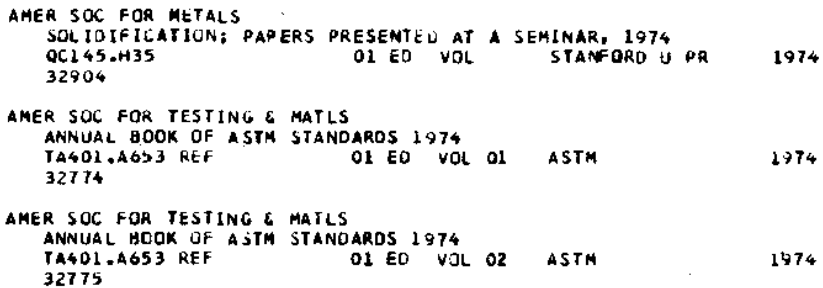

1974

FIG. 32 ALL BOOKS WITH CALL NUMBER BY AUTHOR AND TITLE (Report Codes 3 and 4)

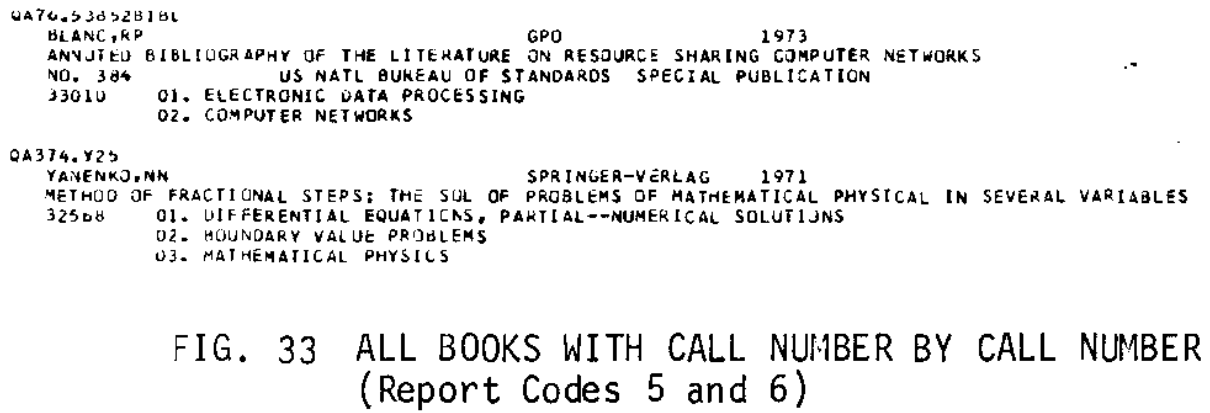

FIG. 33 ALL BOOKS WITH CALL NUMBER BY CALL NUMBER (Report Codes 5 and 6) 


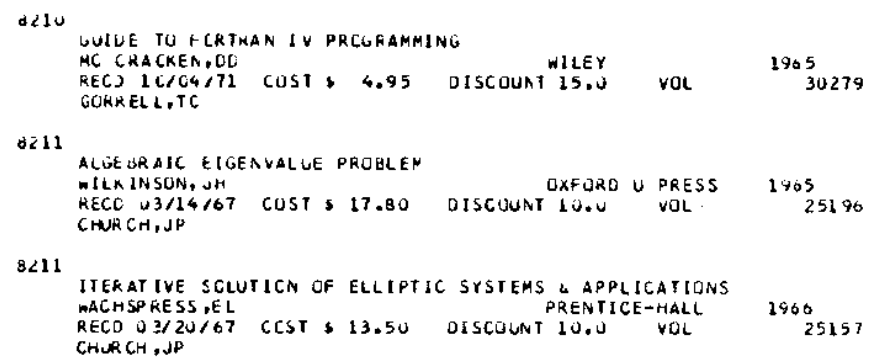

FIG. 34 ALL BOOKS BY DEPARTMENTAL COST CODE AND DATE RECEIVED (Report Code 7)

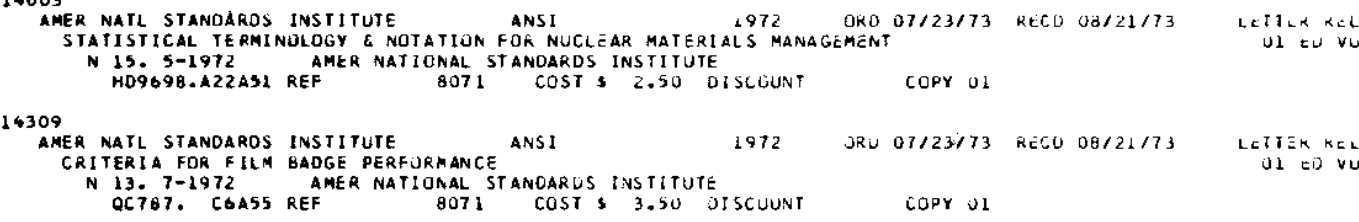

FIG. 35 ALL BOOKS BY ACCESSION NUMBER (Report Codes 8 and 9)

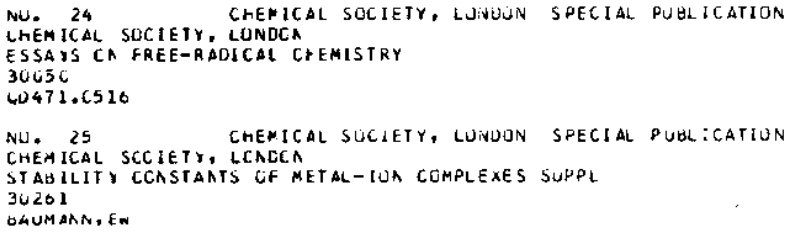

FIG. 36 ALL BOOKS WITH SERIES BY SERIES (Report Codes 10 and 11 )

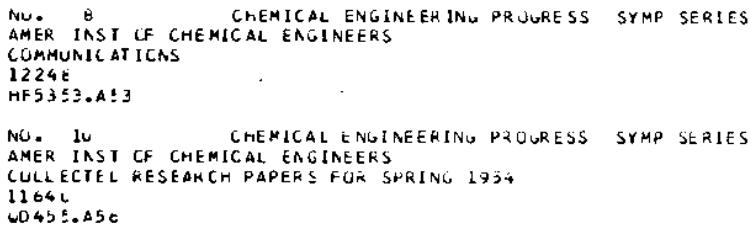

FIG. 37 ALL BOOKS WITH CALL NUMBER AND SERIES BY SERIES (Report Codes 12 and 13) 


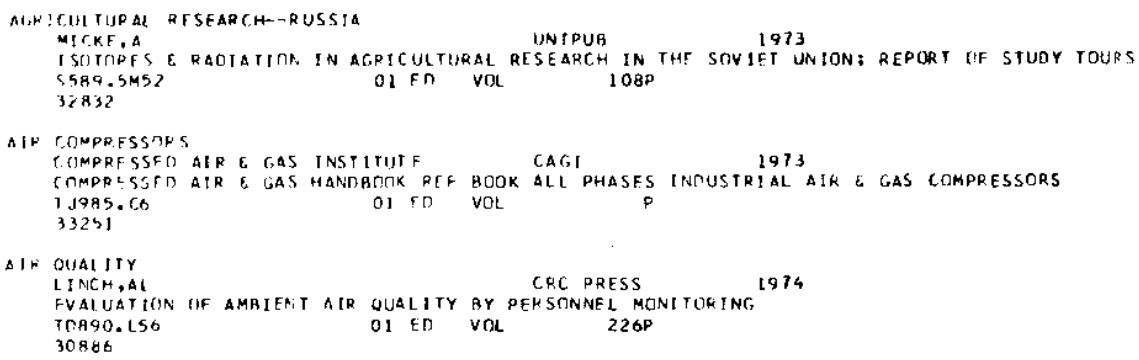

FIG. 38 ALL BOOKS WITH CALL NUMBER BY SUBJECT AND AUTHOR (Report Codes 14 and 15)

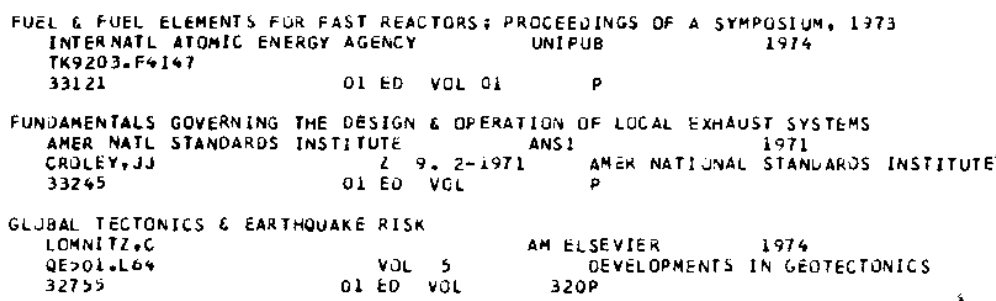

0. $\underset{\text { EOL }}{\text { VOL }}$

AM ELSEVIER 1974 $320 \mathrm{P}$ OEVELOPMENTS IN GEOTECTONICS

FIG. 39 ALL BOOKS BY TITLE AND AUTHOR (Report Codes 16 and 17)

\begin{tabular}{|c|c|c|c|c|c|c|}
\hline $\begin{array}{c}\text { FHCTCMICROGRAPHY } \\
\text { MAREEA, TJ }\end{array}$ & 86067734 & 15002 & QH251.A42 & $12 \mathrm{ED}$ & $v 0 t$ & $10 / 27 / 70$ \\
\hline 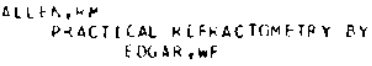 & $\begin{array}{l}\text { MEANS UF THE } \\
\text { WLOG } 1720\end{array}$ & $\begin{array}{r}\text { MICRC SCOPE } \\
11442\end{array}$ & $Q C 3 y 7.44$ & $D 1 E D$ & VOL & $11 / 75 / 72$ \\
\hline 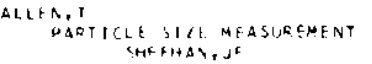 & HL ن 7732 & 30000 & 12418.8443 & $21 E 0$ & VOL & $35 / 14 / 73$ \\
\hline
\end{tabular}

FIG. 40 ALL BOOKS ON LOAN BY AUTHOR AND TITLE (Report Code 18)

\begin{tabular}{|c|c|c|c|c|c|c|}
\hline $\begin{array}{l}\text { BETHMANN,HK } \\
\text { GLASSTONE, S } \\
\text { ELEMENTS OF }\end{array}$ & $\begin{array}{c}\text { BLOG } 221 \mathrm{H} \\
\text { PHYSICAL CMEMISIKY }\end{array}$ & 17239 & 00453.656 & 02 ED & vol & $08 / 25 / 70$ \\
\hline $\begin{array}{l}\text { QETHMANN, HK } \\
\text { PRANOTL EL } \\
\text { ESSENTIALS O }\end{array}$ & $\begin{array}{c}\text { BLOG } 221 F \\
\text { OF FLUIO DYNaMICS }\end{array}$ & 4645 & QA911.P714 & 01 EO & VOL & $07 / 11 / 66$ \\
\hline $\begin{array}{l}\text { BETHMANN, HK } \\
\text { SHER WODU, IK } \\
\text { ABSORPTION E }\end{array}$ & $\begin{array}{l}\text { BLOG } 2 Z 1 F \\
\text { E EXIRACI ION }\end{array}$ & 1738 & IP1S6.A35S & 03 ED & VOL & $04 / 25 / 66$ \\
\hline
\end{tabular}

FIG. 41 ALL BOOKS ON LOAN BY BORROWER, AUTHOR, AND TITLE (Report Code 19) 


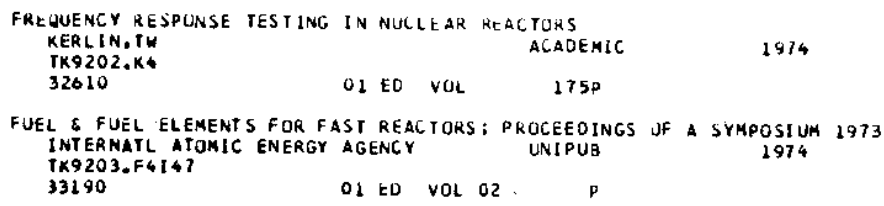

FIG. 42 ALL BOOKS WITH CALL NUMBER BY TITLE AND AUTHOR (Report Codes 20 and 21)

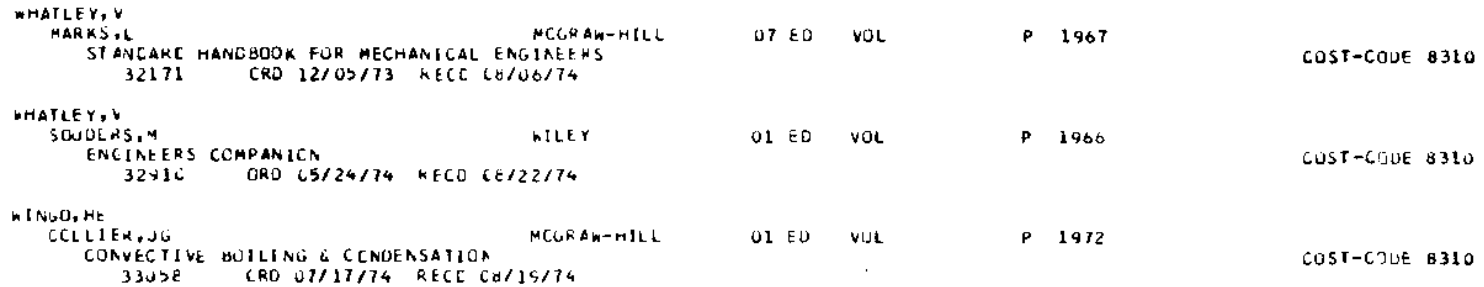

FIG. 43 ALL BOOKS WITHOUT CALL NUMBER BY REQUESTER, AUTHOR, AND TITLE (Report Codes 22 and 23)

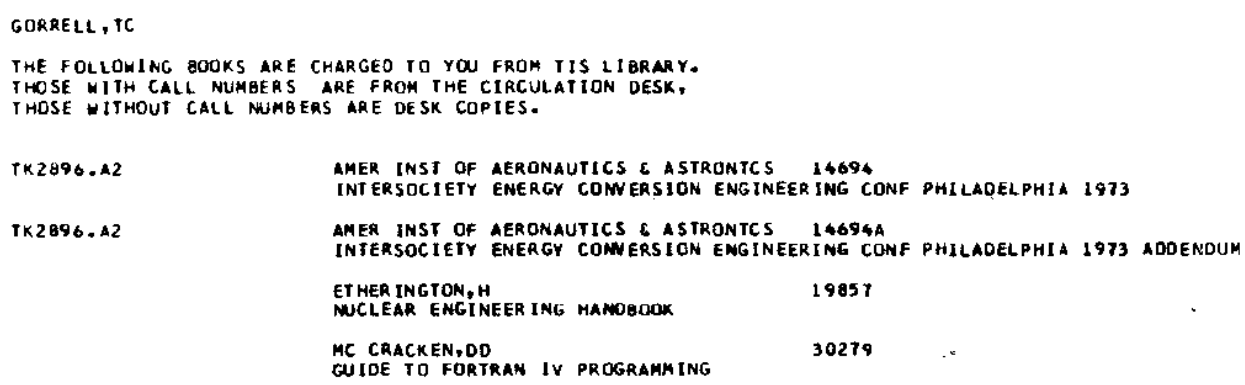

TK2896.A2

AMER INST OF AERONAUTICS E ASTRONTCS 1469 INTERSOCIETY ENERGY CONERSION ENGINEER ING CONF PHILADELPHIA 1973

TK2896.A2

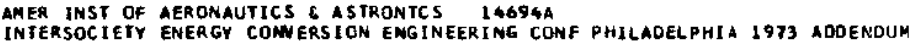

FIG. 44 ALL BOOKS LOANED TO A BORROWER BY EITHER REQUESTER OR BORROWER (Report Code 24) 
THE FOLLOWING BOOK (S) MAYE BEEN ON LOAN TO YOU FOR MORE THAN TWO

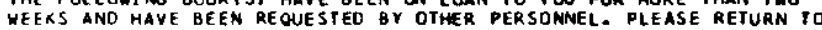

TIS LIBRARY BLDG 773A

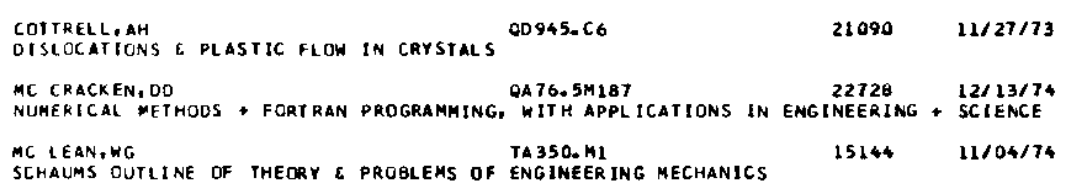

FIG. 45 ALL BOOKS WITH CALL NUMBER LOANED TO A BORROWER BY BORROWER, AUTHOR, AND TITLE (Report Code 25)

IO BUWEKS,BL

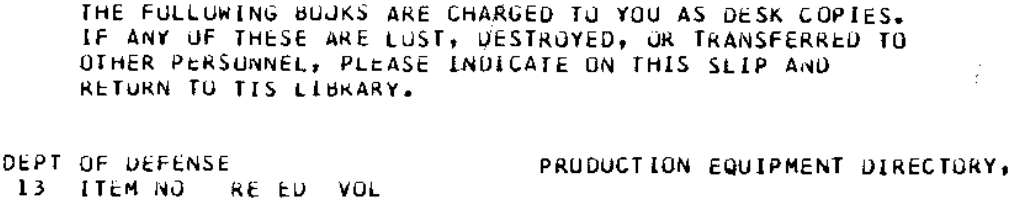

FIG. 46 ALL BOOKS WITHOUT CALL NUMBER BY REQUESTER, AUTHOR, AND ACCESSION NUMBER (Report Code 26)

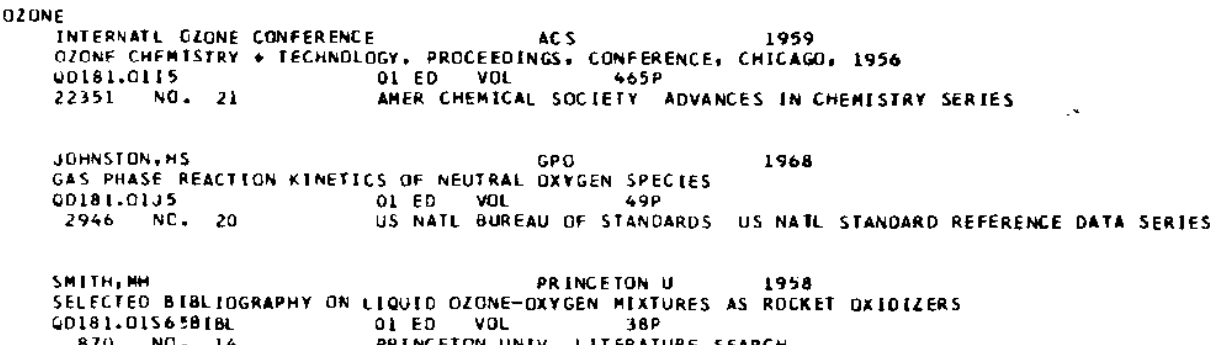

FIG. 47 ALL BOOKS CATALOGED UNDER A PARTICULAR SUBJECT (Report Code 27)

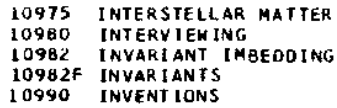

FIG. 48 ALL SERIES AND SUBJECT CODES WITH THEIR CORRESPONDING ALPHABETIC HEADINGS (Report Code 28) 


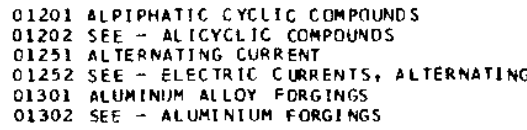

FIG. 49 ALL SUBJECT CROSS REFERENCES

(Report Code 29) 


\section{APPENDIX D Input and Error List for Update Program}

ADD S-S The information on the following card was added to the Master File as a subject or series entry.

CH S-S The subject or series heading on the following card replaced the subject or series heading with the corresponding code number in the Master File.

DE S-S The following subject or series entry was deleted from the Master File.

ADD XREF The information on the following card was added to the Master File as a subject cross-reference entry.

CH XREF

The cross-reference heading on the following card replaced the cross-reference heading with the corresponding code number on the Master File.

DE XREF The following subject cross-reference entry was deleted from the Master File.

ADD

The information on the following card was added to the Master File as a part of a book entry.

$\mathrm{CH}$ The items shown on the following card have replaced corresponding fields in an existing book record.

DE 1 The following card image was deleted from an existing book record on the Master File.

DE The following complete book record was deleted from the master tape.

ERROR-1 The following new book record card has the same accession number as an existing book record. This card has been discarded.

ERROR-4 More than one Card 1 with the same accession number has been submitted for a new book record. This card has been discarded.

ERROR-5 More than one Card 2 with the same accession number has been submitted for a new book record. This card has been discarded. 
ERROR-6 More than one Card 3 with the same accession number has been submitted for a new book record. This card has been discarded.

ERROR-7 More than one Card 4 with the same accession number has been submitted. This card has been discarded.

ERROR-8 More than three Card 6's with the same accession number have been submitted for a new book record. This card has been discarded.

ERROR-9 More than three Card 7's with the same accession number have been submitted for a new book record. This card has been discarded.

ERROR-10 More than one Card 5 with the same accession number has been submitted for a new book record. This card has been discarded.

ERROR-11 More than one Card 8 with the same accession number has been submitted for a new book record. This card has been discarded.

ERROR-12 More than one Card 9 with the same accession number has been submitted for a new book record. This card has been discarded.

ERROR-14 No existing book record has the same accession number as this change or deletion card. This card has been discarded.

ERROR-30 An incomplete set of new book record cards has been submitted. These cards have been "discarded. The cards necessary for a complete set are Cards 1,3 , and 4 .

ERROR-40 The subject (or series) code indicated in the message was not found in the subject (or series) file. Cards 4,5 , and 8 are printed on the error report to facilitate locating the bad code.

ERROR-65 The following new subject or series record has the same code number as an existing subject or series record. This card has been discarded.

ERROR-70 No existing subject or series record has the same code number as this correction or deletion card. This card has been discarded.

ERROR-75 This new subject or series code number was submitted more than once. This card has been discarcled. 
ERROR-80 The following new subject cross-reference record has the same code number as an existing subject crossreference record. This card has been discarded.

ERROR-85 No existing subject cross-reference record has the same code number as this change or deletion card. This card has been discarded.

ERROR-90 This new subject cross-reference code number was submitted more than once. This card has been discarded. 